\title{
Spatial variability of phytoplankton, nutrients and new production estimates in the waters around Svalbard
}

\author{
Georgina Owrid, Giorgio Socal, Giuseppe Civitarese, \\ Anna Luchetta, Jozef Wiktor, Eva-Maria Nöthig, \\ Inger Andreassen, Ursula Schauer \& Volker Strass
}

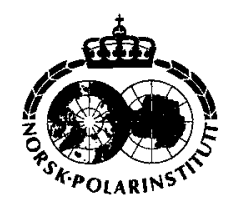

\begin{abstract}
Phytoplankton dynamics and carbon input into Arctic and sub-Arctic ecosystems were investigated around Svalbard, in summer 1991. Phytoplankton biomass, species composition and dissolved nutrient concentrations were analysed from water samples collected along seven transects. Phytoplankton biomass was low especially to the north (Chlorophyll- $a$ mean $0.3 \mu \mathrm{g} \mathrm{I}^{-1}$ ), where flagellates dominated the communities and only ice-diatoms were present. To the west, the phytoplankton composition was representative of a summer Atlantic community, in a post-bloom state. Zooplankton grazing, mainly by copepods, appeared to be the main control on biomass to the west and north of Svalbard.

In the Barents Sea (east of Svalbard), an ice edge bloom was observed (Chlorophyll- $a$ max. $6.8 \mu \mathrm{gl}^{-1}$ ) and the ice edge receded at a rate of approximately $11 \mathrm{~km} \mathrm{day}^{-1}$. The phytoplankton community was represented by marginal ice species, especially Phaeocystis pouchetii and Chaetoceros socialis. South of the ice edge, Deep Chlorophyll Maxima (DCM) were observed, as surface waters became progressively nutrient-depleted. In these surface waters, the phytoplankton were predominantly auto- and heterotrophic flagellates.

Carbon production measurements revealed high net production (new and regenerated) to the north of the Barents Sea Polar Front (BSPF); it was especially high at the receding ice edge (reaching $1.44 \mathrm{~g} \mathrm{C} \mathrm{m}^{-2} \mathrm{day}^{-1}$ ). To the south, a low level of production was maintained, mainly through regenerative processes.
\end{abstract}

G. Owrid, School of Ocean and Earth Sciences, University of Southampton, European Way, SOI4 3ZH Southampton, UK; G. Socal, Institute of Marine Biology C.N.R., Castello 1364/A, 30122 Venice, Italy; G. Civitarese \& A. Luchetta, Thalassographic Institute of Trieste. C.N.R., 34123 Trieste, Italy; J. Wiktor, Arctic Ecology Group, Institute of Oceanology, 81-712. PAN Sopot, Poland; E.-M. Nöthig, U. Schauer \& V. Strass, Alfred Wegener Institute for Polar and Marine Research, D-2850 Bremerhaven, Germany; 1. Andreassen, Norwegian College of Fishery Science, University of Troms $\phi$, Troms $\phi$ N-9037, Norway.

Spatial heterogeneity of phytoplankton communities has been well documented for the temperate latitudes (e.g. Venrick 1988, 1990: Weeks et al. 1995). In contrast, little is known of the distribution, abundance and variability of plankton in icecovered seas, mainly due to the inaccessibility of these waters throughout a major part of the year. Some progress has been made in the last few years in these polar regions, with the improvement in the capabilities of ice-breakers that enable the collection of information at the marginal ice zone and in the water column under the pack ice (Rey \& Loeng 
1985; Smith 1987; Codispoti et al. 1991; Syvertsen 1991, Bianchi et al. 1992; Villafañe et al. 1993). Measurements of temporal and spatial variability of phytoplankton blooms and the subsequent input of organic matter into this marine system are of importance to our understanding of the pelagic and benthic ecology of the Arctic regions.

Svalbard, at the western boundary of the Barents Sea and the eastern boundary of the Greenland Sea, is exposed to a variety of hydrological and geological regimes. To the west and south-west, relatively warm, more saline and nutrient-poor Atlantic Waters cover the narrow continental shelf. To the east, colder, less saline and comparatively nutrient-rich Barents Sea Waters cover a wide shallow shelf with water depths of 100 to $400 \mathrm{~m}$. Arctic Waters are advected from the north and east in the upper layer, which flows in a boundary current along the continental slope to the west and north of Svalbard. Additionally, local transformation of water masses occurs through freezing and ice melt.

In the central Barents Sea (to the east of Svalbard), a permanent frontal system, the Barents Sea Polar Front (BSPF), is formed between Modified Atlantic Water and Arctic Water. The position of BSPF varies between $72^{\circ}$ and $77^{\circ} \mathrm{N}$; the location and extent depends upon the season and climatic conditions (Loeng 1989); seasonal ice cover can vary by up to $50 \%$ (Vinje \& Kvambekk 1991).

The ecology of the Barents Sea has been investigated over a number of years as an important component of the productive northern fisheries. Much of this information has come from Norwegian and Russian research programmes (see, for example, Nesvetova \& Rhyzhov 1987; Bămstedt et al. 1991; Mehl 1991; RAS 1992). Results from a comprehensive biological study of the Barents Sea, the Norwegian Research Programme for Marine Arctic Ecology (PRO MARE), have been published (Sakshaug et al. 1991). However, the ecology of waters to the west and north of Svalbard is less well known (see Strömberg 1989) and there is little information for ice-covered regions during the winter-spring period.

The Study of the European Arctic Shelf (SEAS) provided the opportunity to carry out a broad ecological investigation of the pelagial around Svalbard, including the central Barents Sea. Within the framework of this study, different aspects of the ecosystem were investigated, including phytoplankton and zooplankton distributions, benthic communities and sediments. Some of these data are described elsewhere (Hulth et al. 1996; Kendall 1996; Piepenburg et al. 1996; Strass \& Nöthig 1996).

In this paper, the distribution of phytoplankton in relation to sea ice, hydrography and nutrients is described. Production estimates, calculated from nutrient and oxygen measurements, are presented for the central and northern Barents Sea, and the role of phytoplankton dynamics in carbon production in these seasonally ice-covered waters is discussed.

\section{Material and methods}

The SEAS cruise, which started and finished in Troms $\emptyset$, Norway, took place from 20 June to 30 July 1991. During the cruise, seven transects were completed (Table 1, Fig. 1). The locations of all the stations, together with a record of the date, time and deployment of sampling equipment have been described elsewhere (Rachor 1992).

At each station, vertical profiles of temperature and salinity were obtained from a CTD (see Schauer 1995). In situ fluorescence data was obtained from a BACKSCAT fluorometer attached to the CTD. Fluorescence readings were calibrated using chlorophyll concentrations measured from discrete water samples (see Strass \& Nöthig 1996).

Water samples for the analysis of nutrients, chlorophyll- $a$, phytoplankton biomass and species composition were collected from 12 litre Niskin water bottles lowered with the CTD. Nitrite $(\mathrm{N}$ $\left.\mathrm{NO}_{2}{ }^{-}\right)$, nitrate $\left(\mathrm{N}-\mathrm{NO}_{3}{ }^{-}\right)$, phosphate $\left(\mathrm{P}-\mathrm{PO}_{4}{ }^{3-}\right.$ ) and silicate $\left(\mathrm{Si}_{-} \mathrm{SiO}_{4}{ }^{4-}\right)$ were analysed directly using a Chemlab Continuous Flow Analyser, according to Grasshoff et al. (1983). Ammonia $\left(\mathrm{N}-\mathrm{NH}_{4}{ }^{+}\right.$) was measured manually after Liddicoat et al. (1975) as modified by Catalano (1987). Oxygen measurements were also made following the Winkler method (Strickland \& Parsons 1972).

Water samples for bulk chlorophyll- $a$ analysis were collected from the euphotic zone (to depths of $200 \mathrm{~m}$ ) at discrete levels, according to fluorometric readings, with increased vertical resolution around the depth of maximum fluorescence. Chlorophyll- $a$ concentrations were determined via the fluorometric method described by Evans et al. (1987). Between 0.5 and 1.01 of seawater was filtered through Whatman $\mathrm{GF} / \mathrm{C}$ filters and 
Table 1. Transect details (see Fig. 1).

\begin{tabular}{|c|c|c|c|c|}
\hline Transect & Date (1991) & Start position & End position & Stations \\
\hline Polat Front (I) & 24-25 June & $\begin{array}{l}77^{\circ} 27.2^{\prime} \mathrm{N} \\
33^{\circ} 03.0^{\prime} \mathrm{E}\end{array}$ & $\begin{array}{l}75^{\circ} 59.0^{\prime} \mathrm{N} \\
34^{\circ} 49.0^{\prime} \mathrm{E}\end{array}$ & $41-45$ \\
\hline Kongsfjordrenna (II) & 3-5 July & $\begin{array}{l}79^{\circ} 00.0^{\prime} \mathrm{N} \\
05^{\circ} 59.0^{\prime} \mathrm{E}\end{array}$ & $\begin{array}{l}79^{\circ} 01.1^{\prime} \mathrm{N} \\
10^{\circ} 44.4^{\prime} \mathrm{E}\end{array}$ & $78-82$ \\
\hline Yermak Plateau (III) & 6-8 July & $\begin{array}{l}80^{\circ} 23.4^{\prime} \mathrm{N} \\
07^{\circ} 33.0^{\prime} \mathrm{E}\end{array}$ & $\begin{array}{l}79^{\circ} 58.3^{\prime} \mathrm{N} \\
11^{\circ} 13.6^{\prime} \mathrm{E}\end{array}$ & $84-90$ \\
\hline Sjuøyane (IV) & 9-10 July & $\begin{array}{l}80^{\circ} 48.1^{\prime} \mathrm{N} \\
18^{\circ} 37.7^{\prime} \mathrm{E}\end{array}$ & $\begin{array}{l}81^{\circ} 33.6^{\prime} \mathrm{N} \\
15^{\circ} 39.4^{\prime} \mathrm{E}\end{array}$ & $93-99$ \\
\hline North-eastern slope (V) & 14-17 July & $\begin{array}{l}81^{\circ} 27.1^{\prime} \mathrm{N} \\
31^{\circ} 34.7^{\prime} \mathrm{E}\end{array}$ & $\begin{array}{l}81^{\circ} 41.7^{\prime} \mathrm{N} \\
30^{\circ} 29.2^{\prime} \mathrm{E}\end{array}$ & $104-109$ \\
\hline Kvitøya (VI) & 20-21 July & $\begin{array}{l}80^{\prime} 50.9^{\prime} \mathrm{N} \\
30^{\circ} 38.1^{\prime} \mathrm{E}\end{array}$ & $\begin{array}{l}80^{\prime \prime} 44.8^{\prime} \mathrm{N} \\
29^{\circ} 28.4^{\prime} \mathrm{E}\end{array}$ & $116-119$ \\
\hline Central Barents Sea (VII) & 21-27 July & $\begin{array}{l}80^{\circ} 41.9^{\prime} \mathrm{N} \\
28^{\circ} 33.5^{\prime} \mathrm{E}\end{array}$ & $\begin{array}{l}76^{\circ} 00.2^{\prime} \mathrm{N} \\
34^{\circ} 49.5^{\prime} \mathrm{E}\end{array}$ & $121-146$ \\
\hline
\end{tabular}

chlorophyll- $a$ was extracted with $90 \%$ acetone. Samples were analysed onboard. The use of GF/C filters may have resulted in an underestimation of phytoplankton biomass at those stations where the phytoplankton population was in a post-bloom state and the smaller flagellates dominated. However we were able to compare chlorophyll data from $10 \mathrm{~m}$ depth (using GF/F filters) collected on the same cruise (for horizontal variability study), with the data included here (GF/C filters) and there was no significant difference between the measurements.

Samples for qualitative and quantitative analysis of phytoplankton were collected at depths of $0 \mathrm{~m}, 20 \mathrm{~m}$ and $40 \mathrm{~m}$. Additional samples were collected at the depths of fluorescence maximum and down to $1 \%$ PAR. Samples were fixed with hexamethylentetramine-buffered formalin and counts taken under an inverted microscope (Utermöhl 1958). Cell volume was estimated from cell measurements (Edler 1979), and carbon content was calculated using conversion factors (Strathmann 1967; Smetacek 1975). In addition, for the analyses of species composition, living phytoplankton samples were collected at 67 stations, from the upper $10 \mathrm{~m}$ of the water column, by an Apstein net (10 and $20 \mu \mathrm{m}$ mesh sizes). Samples were directly analysed onboard using an inverted microscope equipped with a video.

\section{Net and new production calculations}

Nutrient consumption in the Upper Mixed Layer (UML) was calculated at five stations in the Barents Sea Polar Front (BSPF) region, in June and again in July when these stations were revisited. The station pairs were $41 / 138,43 / 142$, 40/143, 44/144, and 45/146 (Fig 1). Temperature and salinity of the core of the designated "winter water masses", i.e. waters that had been icecovered and were high in nutrients (at $30-60 \mathrm{~m}$ depth), did not vary temporally, except at the southernmost station. Thus, it was assumed that there was no significant advection of water in the upper $60 \mathrm{~m}$ during this period. The uptake was calculated in $\mathrm{mM} \mathrm{m}^{-2}$, transformed into new production estimates (after Redfield et al. 1963) and expressed in $\mathrm{g}$ Carbon $\mathrm{m}^{-2}$ day $^{-1}$. The thickness of the UML, taken as the layer with salinities $<34.2 \mathrm{psu}$, was determined after Mitchell \& Holm-Hansen (1991). The methodology used to obtain these estimates for this data set has been described and discussed elsewhere (Luchetta et al. in press). Estimates of new production were calculated following the removal of nitrate, after Jennings et al. (1984), and compared with estimates obtained from Apparent Oxygen Utilization (AOU) variation, following the definition of net community production given by Minas et al. (1986) and Jenkins \& Wallace (1992).

Net and new production were estimated also at stations located in the northern Barents Sea (stations 132-137), which were sampled only once during the cruise. Prior to ice retreat, it was assumed that the productivity at these stations would reflect a winter situation. The ice edge retreated by approximately $11 \mathrm{~km}^{-1 a y}{ }^{-1}$ and this enabled the calculation of the productive time period for each station, i.e. the period between ice retreat and when water samples were collected (ranging between 11 and 27 days). Hence, a 


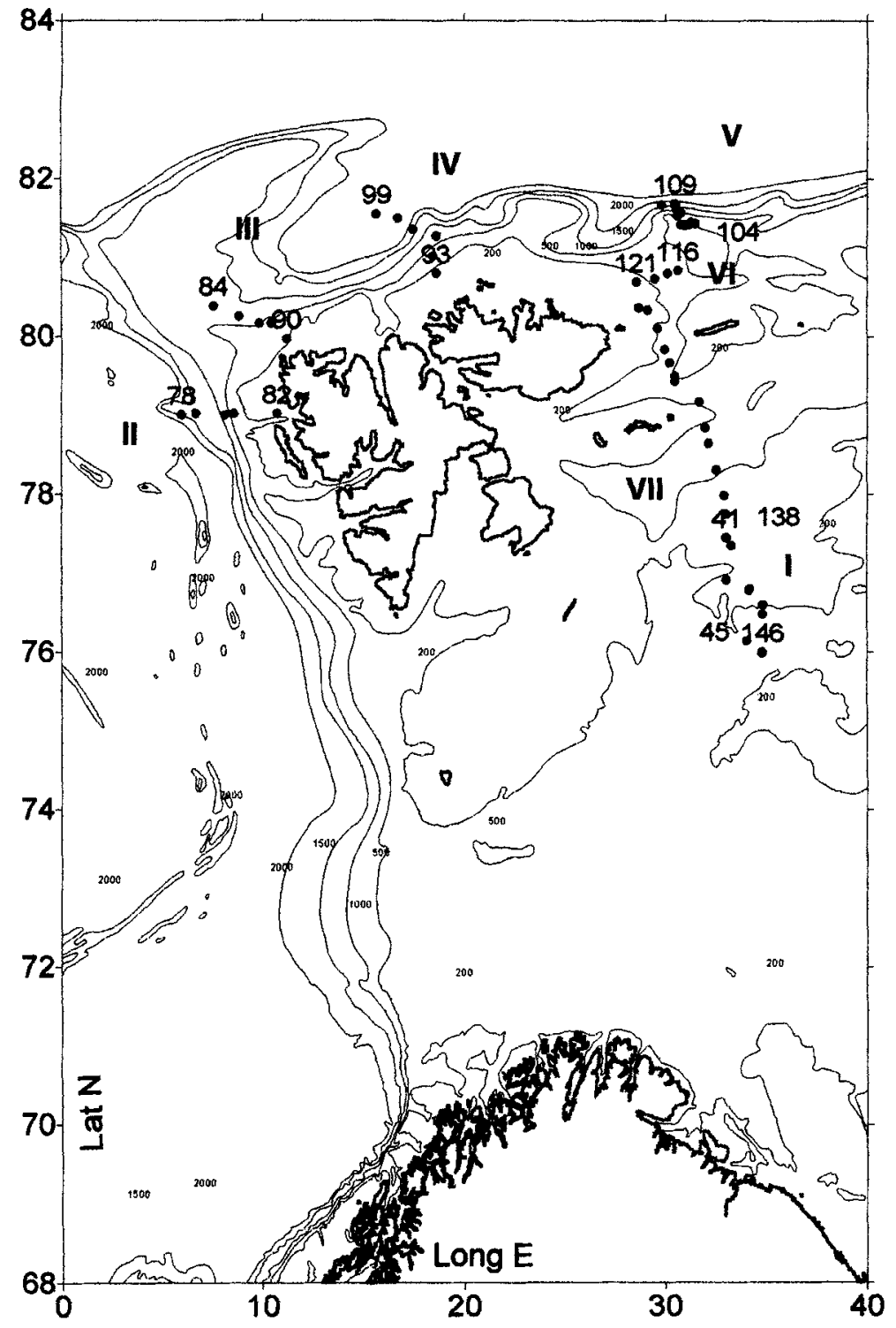

Fig. 1. Location of the transects during the SEAS cruise in the waters around Svalbard. See Table 1 for details.

comparison between the nutrient and oxygen data with those typifying a winter situation, such as that found at Station 121, revealed the rate of production that had taken place since the waters became ice-free.

\section{Results}

The spatial variability in phytoplankton abundance, species composition and productivity in the waters around Svalbard shows clearly the influence of the various hydrological regimes (Tables $2,3,4,5$ ) and sea ice conditions (Inall \& Parker 1992; Fig. 2). For this reason, the results are described under the three main hydrological provinces and in chronological order (with the exception of Transect I, which is discussed in the central Barents Sea section). The data (salinity, temperature, phytoplankton, oxygen and nutrients) are described for each transect; however, only representative profiles are depicted graphically. 
Table 2. Range, means and confidence limits for the oceanographic parameters in the different areas around Svalbard.

\begin{tabular}{|c|c|c|c|c|c|c|c|c|c|}
\hline & Sal. (psu) & Temp. $\left({ }^{\circ} \mathrm{C}\right)$ & Oxg. (\%) & $\begin{array}{c}\mathrm{NH}_{4} \\
\mu \mathrm{M}\end{array}$ & $\begin{array}{c}\mathrm{NO}_{3} \\
\mu \mathrm{M}\end{array}$ & $\begin{array}{l}\mathrm{PO}_{4} \\
\mu \mathrm{M}\end{array}$ & $\begin{array}{c}\mathrm{SiO}_{4} \\
\mu \mathrm{M}\end{array}$ & $\begin{array}{c}\text { PPC } \\
\mu \mathrm{gl}^{-1}\end{array}$ & $\begin{array}{l}\mathrm{CHLa} \\
\mu_{\mathrm{g} \mathrm{l}}^{-1}\end{array}$ \\
\hline & \multicolumn{9}{|c|}{ West of Svalbard stations $70-90$} \\
\hline Range & $33.0-35.1$ & $0.5-5.8$ & $73-121$ & $0-2.2$ & $0.3-12.8$ & $0.10-1.13$ & $0-5.3$ & $0-91$ & $0-3.0$ \\
\hline Mean & 34.9 & 4.3 & 102 & 0.7 & 8.0 & 0.45 & 3.2 & 11 & 0.8 \\
\hline \multirow[t]{2}{*}{ Conf. lim. } & 0.1 & 0.2 & 2 & 0.1 & 0.4 & 0.02 & 0.2 & 4 & 0.3 \\
\hline & \multicolumn{9}{|c|}{ North of Svalbard stations 93-121 (except 119) } \\
\hline Range & $33.0-35.0$ & $-1.8-3.5$ & $77-115$ & $0-1.8$ & $1.1-12.5$ & $0.16-0.77$ & $0-5.2$ & $0-13$ & $0-1.1$ \\
\hline Mean & 34.3 & -0.4 & 96 & 0.4 & 9.2 & 0.56 & 3.7 & 3 & 0.3 \\
\hline Conf. lim. & 0.1 & 0.2 & 1 & 0.1 & 0.3 & 0.02 & 0.1 & 1 & 0.1 \\
\hline \multicolumn{10}{|c|}{ Central Barents Sea stations 40-47; 119: $123-146$} \\
\hline Range & $31.3-35.0$ & $-1.8-3.7$ & $88-127$ & $0-2.2$ & $0-12.8$ & $0.04-0.83$ & $0-6.3$ & $0-144$ & $0-6.8$ \\
\hline Mean & 34.2 & -0.6 & 101 & 0.3 & 6.4 & 0.44 & 2.2 & 26 & 1.3 \\
\hline Conf. lim. & 0.1 & 0.2 & 1 & 0.04 & 0.5 & 0.05 & 0.2 & 6 & 0.3 \\
\hline
\end{tabular}

\section{West of Svalbard}

\section{Transect II: Kongsfjordrenna (Figs. 3, 4)}

Ice-free waters of Atlantic origin occupied the euphotic zone (Table 2). Salinity ( $\mathrm{S}=35.0 \mathrm{psu}$ ), temperature $\left(\mathrm{T}=3.5\right.$ to $\left.5.0^{\circ} \mathrm{C}\right)$ and nutrient concentrations (maximum values: $\mathrm{NO}_{3}=13 \mu \mathrm{M}$, $\mathrm{SiO}_{4}=6 \mu \mathrm{M}$ ) were high. At the surface, outflow of the fiordic waters was evident in salinity and nutrient profiles (Figs. 3b, Fig. 4b, c, d); this region is heavily influenced by large amounts of freshwater run-off from glaciers during the summer period (Eilertsen et al. 1989).

Strong horizontal gradients of Apparent Oxygen Utilization (AOU) and nutrients are clearly recognizable in the middle of the transect, with the Svalbard shelf waters being poorer in nutrients than the offshore waters. Chlorophyll- $a$ and PhytoPlankton Carbon (PPC) levels were generally low throughout the transect (Fig. 3d, Table 2), even though nutrients were not limiting at this time (Fig. 4b, c, d). Towards the Svalbard shelf, the Chlorophyll- $a$ and AOU distribution indicate that biological production has occurred. However, the high ammonia levels (Fig. 4a) and a corresponding increase in biomass of copepods, mainly Calanus finmarchicus (Fransz et al. 1992), suggest that zooplankton grazing may have reduced the phytoplankton biomass.

These bio-chemical gradients, albeit small, were reflected in phytoplankton abundance and species composition. In this frontal zone (Stations 77-81), dominant phytoplankton species changed from cryptophyceans (west) to other flagellates and
Table 3. Net and new primary production in the central Barents Sea and in the frontal region (repeated stations) expressed as $\mathrm{g} \mathrm{C} \mathrm{m}^{-2}$ day $^{-1}$. The values were integrated for the upper mixed layer (UML)

\begin{tabular}{lccc}
\hline Stations & $\begin{array}{c}\text { Depth } \\
\mathrm{m}\end{array}$ & $\begin{array}{c}\text { New production } \\
\mathrm{NO}_{3} \text { uptake }\end{array}$ & $\begin{array}{c}\text { Net community } \\
\text { production A O U } \\
\text { release }\end{array}$ \\
\hline 132 & 30 & 1.43 & 1.44 \\
133 & 30 & 0.98 & 0.99 \\
135 & 30 & 0.75 & 0.75 \\
137 & 30 & 0.58 & 0.59 \\
$138 / 41$ & 30 & 0.24 & 0.38 \\
$142 / 43$ & 40 & 0.36 & 0.62 \\
$143 / 40$ & 45 & -0.02 & 0.32 \\
$144 / 44$ & 40 & -0.14 & 0.08 \\
$146 / 45$ & 35 & -0.01 & 0.16 \\
\hline
\end{tabular}

Table 4. Chlorophyll- $a$ and phytoplankton biomass (PPC) data in some selected stations. Values were integrated to $100 \mathrm{~m}$ depth.

\begin{tabular}{lrrr}
\hline Transect & Station & $\begin{array}{c}\text { Chl } a \\
\mathrm{mg} \mathrm{m}^{-2}\end{array}$ & $\begin{array}{c}\mathrm{PPC} \\
\mathrm{g} \mathrm{C} \mathrm{m}^{-2}\end{array}$ \\
\hline Polar Front transect & 41 & 90.4 & 2.7 \\
Polar Front transect & 43 & 187.8 & 5.0 \\
Polar Front transect & 45 & 86.2 & 2.3 \\
North-eastern transect & 108 & 11.6 & 0.2 \\
Kvitøya transect & 119 & 138.7 & 3.0 \\
Central Barents Sea transect & 124 & 86.8 & 1.6 \\
Central Barents Sea transect & 131 & 39.1 & 0.9 \\
Central Barents Sea transect & 138 & 139.1 & 3.4 \\
Central Barents Sea transect & 142 & 40.9 & 1.2 \\
Central Barents Sea transect & 146 & 31.0 & 1.3 \\
\hline
\end{tabular}


Table 5. Mean and maximum biomass, and relative occurrence of the dominant species in the different regions around Svalbard.

\begin{tabular}{|c|c|c|c|}
\hline Species & $\begin{array}{c}\text { Mean } \\
\mu \mathrm{g} \mathrm{Cl}^{-1}\end{array}$ & $\begin{array}{c}\text { Max. } \\
\mu \mathrm{g} \mathrm{Cl}^{-1}\end{array}$ & $\begin{array}{c}\text { Rel. occurr. } \\
\%\end{array}$ \\
\hline \multicolumn{4}{|l|}{ West of Svalbard (July) } \\
\hline Cryptomonas sp. $(>12 \mu \mathrm{m})$ & 2.2 & 82.5 & 7 \\
\hline Cryptomonas of pelagica & 1.3 & 10.7 & 63 \\
\hline Unid. naked dinoflagellates $(20 \mu \mathrm{m})$ & 1.0 & 13.2 & 35 \\
\hline Unid. flagellates $(>7 \mu \mathrm{m})$ & 1.0 & 6.7 & 30 \\
\hline Phaeocystis pouchetii & 0.8 & 14.5 & 43 \\
\hline Chaetoceros decipiens & 0.6 & 15.9 & 13 \\
\hline Leucocryptos marina & 0.4 & 7.1 & 37 \\
\hline Prorocentrum sp. & 0.4 & 14.7 & 7 \\
\hline Chaetoceros densus & 0.3 & 10.6 & 9 \\
\hline Fragilariopsis cylindrus & 0.3 & 1.7 & 67 \\
\hline Unid. flagellates $(3 \mu \mathrm{m})$ & 0.2 & 8.3 & 20 \\
\hline Pseudo-nitzchia delicatissima complex & 0.2 & 1.5 & 65 \\
\hline \multicolumn{4}{|l|}{ North of Svalbard (July) } \\
\hline Unid. flagellates $(>7 \mu \mathrm{m})$ & 0.5 & 4.2 & 46 \\
\hline Unid. flagellates $(3 \mu \mathrm{m})$ & 0.2 & 6.2 & 25 \\
\hline Unid. naked dinoflagellates $(20 \mu \mathrm{m})$ & 0.2 & 6.0 & 23 \\
\hline Phaeocystis pouchetii & 0.2 & 4.7 & 46 \\
\hline Eutreptiella sp. & 0.2 & 6.1 & 6 \\
\hline Cryptomonas ef pelagica & 0.2 & 2.4 & 65 \\
\hline Chaetoceros socialis & 0.1 & 4.0 & 8 \\
\hline Unid. naked dinoflagellates $(15 \times 10 \mu \mathrm{m})$ & 0.1 & 0.7 & 35 \\
\hline Gyrodinium $(65 \times 35 \mu \mathrm{m})$ & 0.09 & 2.3 & 6 \\
\hline Thalassiosira cf bioculata & 0.08 & 2.1 & 8 \\
\hline Thalassiosira nordenskioldii & 0.08 & 3.6 & 4 \\
\hline Unid. naked dinoflagellates $(30 \times 20 \mu \mathrm{m})$ & 0.07 & 1.5 & 8 \\
\hline Melosira arctica & 0.06 & 1.0 & 17 \\
\hline Unid. thecats dinoflagellates & 0.06 & 0.7 & 17 \\
\hline Gymnodinium cf simplex & 0.06 & 0.8 & 63 \\
\hline Gyrodinium $\mathrm{sp}(86 \times 60 \mu \mathrm{m})$ & 0.06 & 2.9 & 2 \\
\hline Pyramimonas sp. & 0.05 & 0.59 & 17 \\
\hline \multicolumn{4}{|l|}{ Polar Front (June) } \\
\hline Phaeocystis pouchetii & 8.9 & 56.8 & 73 \\
\hline Amphiprora hyperborea & 7.1 & 125.1 & 27 \\
\hline Thalassiosira cf antarctica & 6.4 & 32.8 & 59 \\
\hline Dinobryon balticum & 2.5 & 22.2 & 59 \\
\hline Lauderia borealis & 1.8 & 39.5 & 9 \\
\hline Nitzchia grunowii & 0.8 & 4.3 & 41 \\
\hline Gyrodinium sp. $(100 \times 45 \mu \mathrm{m})$ & 0.8 & 6.0 & 14 \\
\hline Chaetoceros decipiens & 0.6 & 2.7 & 68 \\
\hline Thalassiosira cf bioculata & 0.7 & 5.1 & 9 \\
\hline Chaetoceros socialis & 0.6 & 3.0 & 9 \\
\hline \multicolumn{4}{|l|}{ Central Barents Sea (July) } \\
\hline Phaeocystis pouchetii & 9.6 & 143.6 & 72 \\
\hline Chaetoceros socialis & 2.3 & 56.7 & 34 \\
\hline Chaetoreros sp. $(15 \times 20 \mu \mathrm{m})$ & 1.2 & 91.1 & 3 \\
\hline Amphiprora hvperborea & 1.0 & 31.9 & 5 \\
\hline Unid. naked dinoflagellates $(30 \times 20 \mu \mathrm{m})$ & 0.9 & 21.6 & 15 \\
\hline Unid. flagellates $(>7 \mu \mathrm{m})$ & 0.7 & 6.9 & 46 \\
\hline Thalassiosira ef nordenskioeldii & 0.7 & 28.3 & 22 \\
\hline Thalassiosira sp. $(30 \times 20 \mu \mathrm{m})$ & 0.6 & 21.3 & 12 \\
\hline Thalassiosira cf antarctica & 0.5 & 10.9 & 19 \\
\hline Unid. flagellates $(3 \mu \mathrm{m})$ & 0.5 & 7.5 & 18 \\
\hline Unid. naked dinoflagellates $(20 \mu \mathrm{m})$ & 0.4 & 8.4 & 20 \\
\hline Thalassiosira of bioculata & 0.4 & 24.7 & 8 \\
\hline Dinobryon balticum & 0.3 & 7.0 & 36 \\
\hline Protoperidinium sp. $(25 \mu \mathrm{m})$ & 0.3 & 8.8 & 5 \\
\hline Nitzschia grunowii & 0.3 & 3.9 & 27 \\
\hline
\end{tabular}




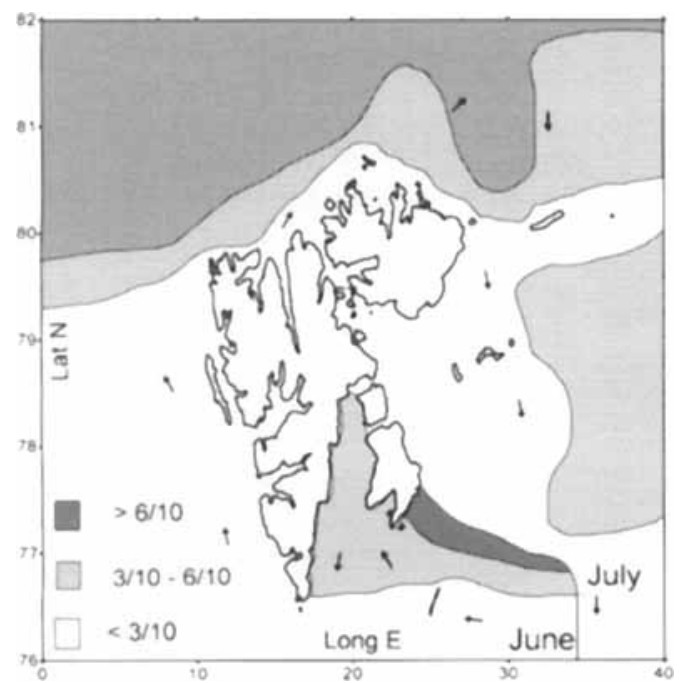

Fig. 2. Ice cover (in tenths) observed during the SEAS cruise, modified from Inall \& Parker (1992). Arrows indicate the cruise track.

prymnesiophyceans (east); a peak in abundance $\left(5 \times 10^{6}\right.$ cells $1^{-1}, 90 \mu \mathrm{g} \mathrm{Cl} 1^{-1}$, at $20 \mathrm{~m}$ depth $)$ was observed due to the presence of Cryptomonas
(Table 5). Also some diatoms, such as Fragilariopsis cylindrus and Pseudo-nitzschia delicatissi$m a$, were well represented.

\section{Transect III: Yermak Plateau (not shown)}

Complete ice cover $(10 / 10)$ occurred at the northernmost stations along the transect (Figs. 1, 2). The euphotic zone was occupied by Atlantic Water (S $>34.9 \mathrm{psu}$ ) with a thin surface layer $(<20 \mathrm{~m})$ of relatively fresh water $(\mathrm{S}=33-34 \mathrm{psu}$, $\mathrm{T}=0$ to $3^{\circ} \mathrm{C}$ ). Nutrients at the surface were not depleted and concentrations increased with depth. At the northern end of the transect, however, some reduction of silicate and nitrate levels $\left(\mathrm{SiO}_{4}<1.0 \mu \mathrm{M}, \mathrm{NO}_{3}<3.0 \mu \mathrm{M}\right)$ occurred. Oxygen saturation was high (more than $112 \%$ ), which coincided with a biomass peak of about $20 \mu \mathrm{g} \mathrm{Cl}^{-1}$ in the surface waters. Chlorophyll- $a$ and biomass were generally low $\left(<1.0 \mu \mathrm{g} \mathrm{l}^{-1}\right)$, with a chlorophyll maximum occurring close to the Svalbard shelf, in the upper $10 \mathrm{~m}$. Flagellates and diatoms dominated the phytoplankton composition (Fig. 5), many of them described as typically ice-associated species such as Chaetoceros septentrionalis, Nitzschia grunowii, Pseudo-nitzschia
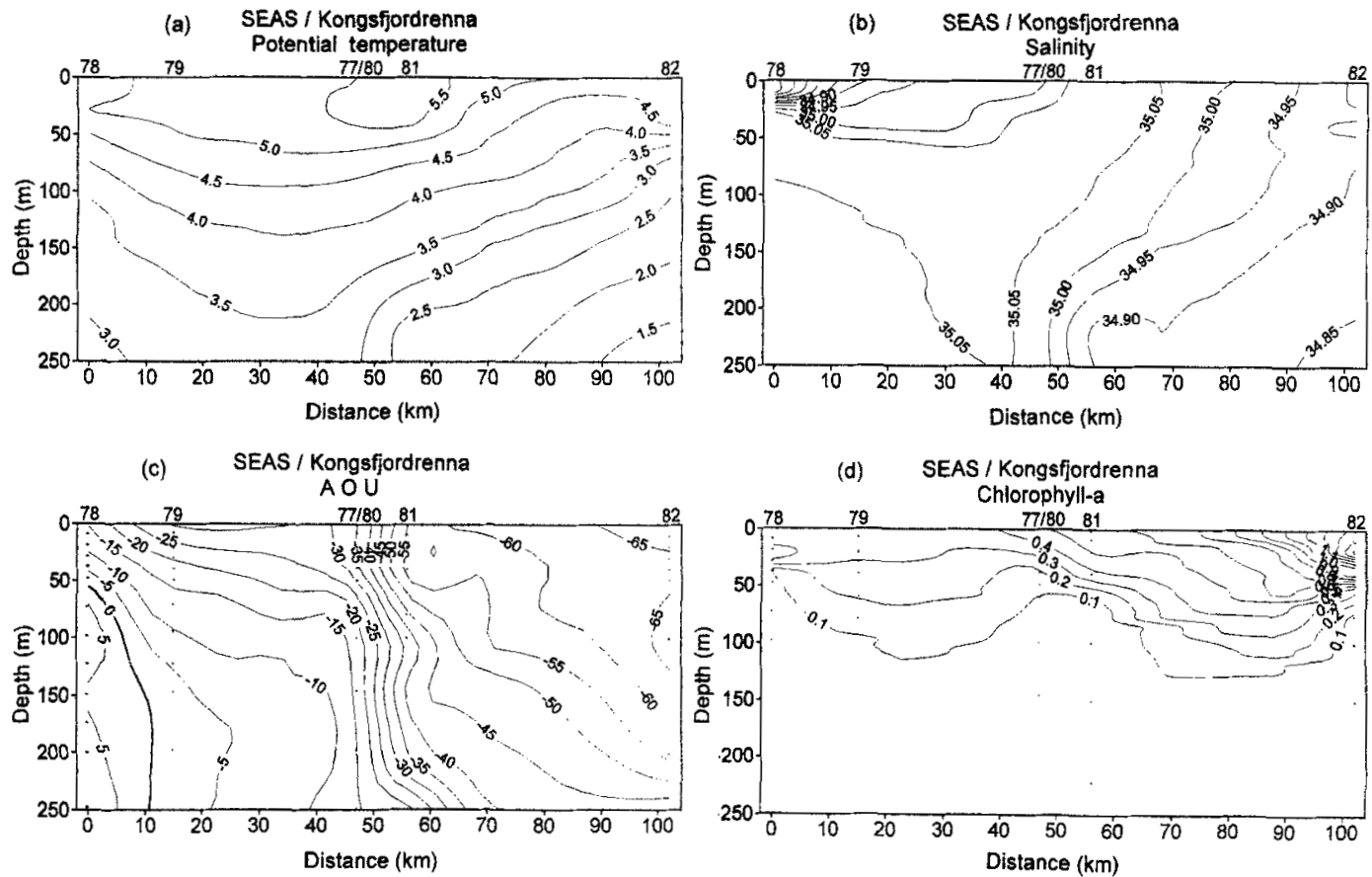

Fig. 3. Vertical distribution of: (a) potential temperature ( $\mathrm{C}$ ): (b) salinity (psu): (c) Apparent Oxygen Utilization (AOU) ( $\mu \mathrm{M}$ ); and (d) chlorophyll- $a\left(\mu \mathrm{g}^{-1}\right)$ along the Kongsfjordrenna transect. 


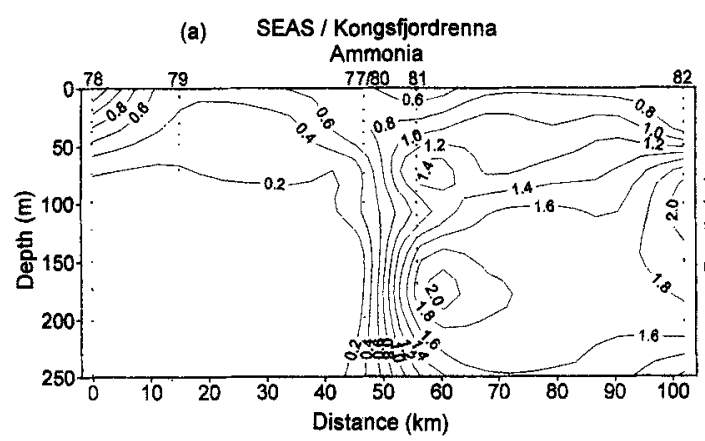

(c) SEAS / Kongsfjordrenna

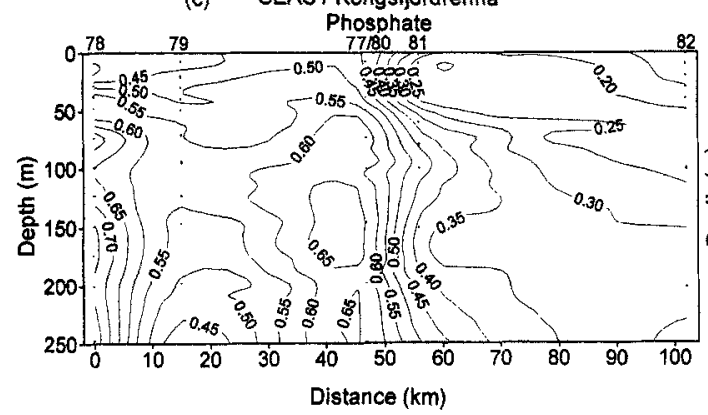

(b) SEAS / Kongsfiordrenna

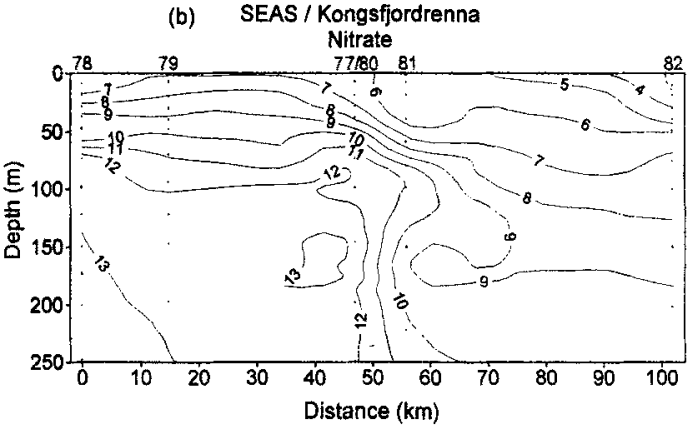

(d) SEAS / Kongsfjordrenna

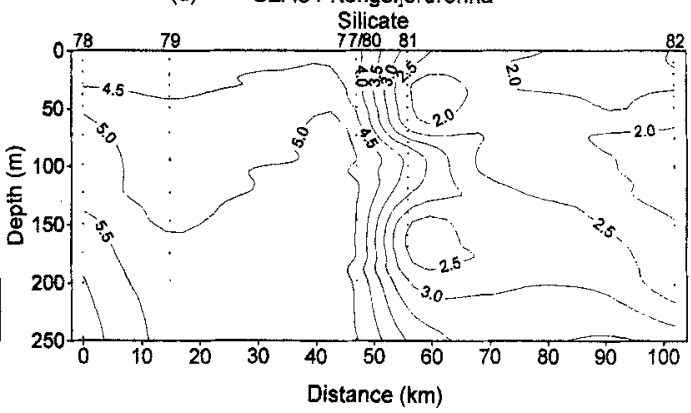

Fig. 4. Vertical distribution of: (a) ammonia $(\mu \mathrm{M})$; (b) nitrate $(\mu \mathrm{M})$; (c) phosphate: and (d) silicate ( $\mu \mathrm{M})$ along the Kongsfjordrenna transect.

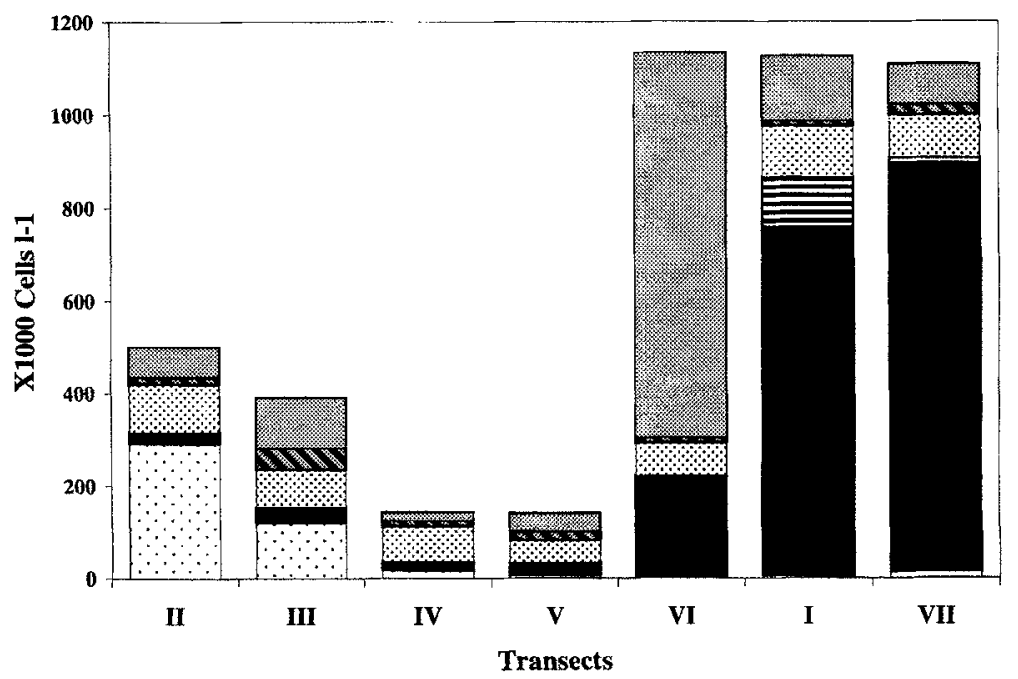

Fig. 5. Abundance (means) of main phytoplankton classes in the waters around Svalbard. Transects:

II = Kongsfjordrenna; III = Sjuøyane ("Seven Islands"); IV = Yermak Plateau; $\mathrm{V}=$ north-eastern slope; VI = Kvitøya; $\mathbf{I}=$ Polar Front; VII = central Barents Sea. 

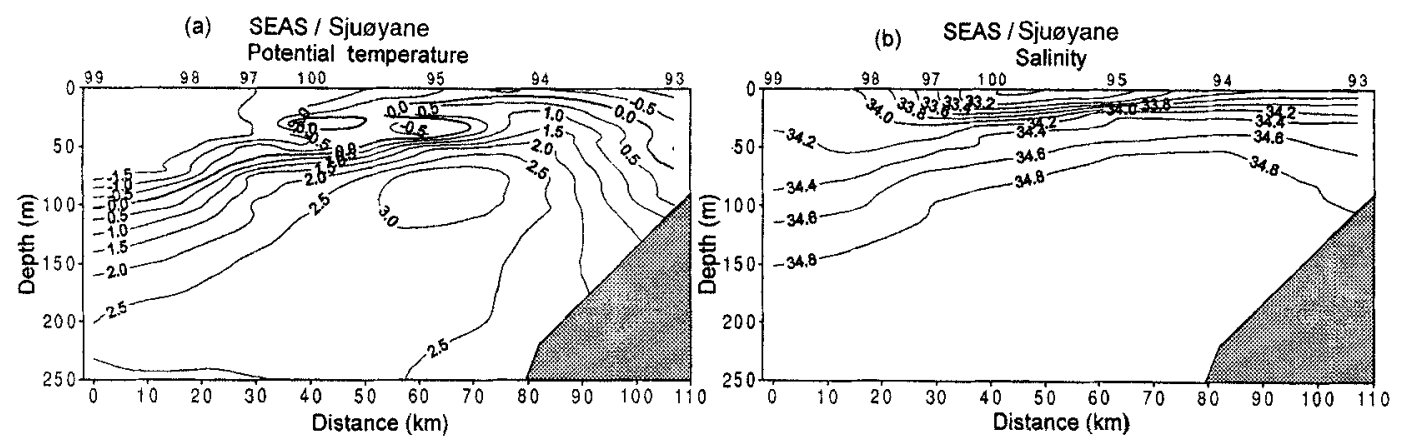

(c) SEAS / Sjuøyane

(d) SEAS / Sjuøyane
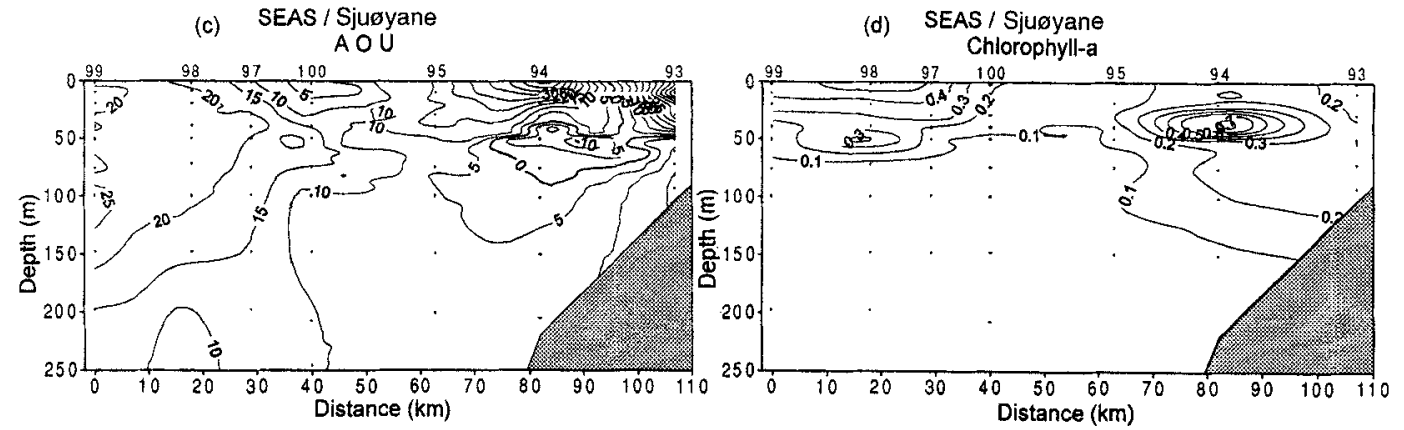

Fig. 6. Vertical distribution of: (a) potential temperature ("C); (b) salinity (psu); (c) Apparent Oxygen Utilization (AOU) ( $\mu \mathrm{M})$; and (d) chlorophyll- $a\left(\mu \mathrm{g} \mathrm{l}^{-1}\right.$ ) along the Sjuøyane transect.
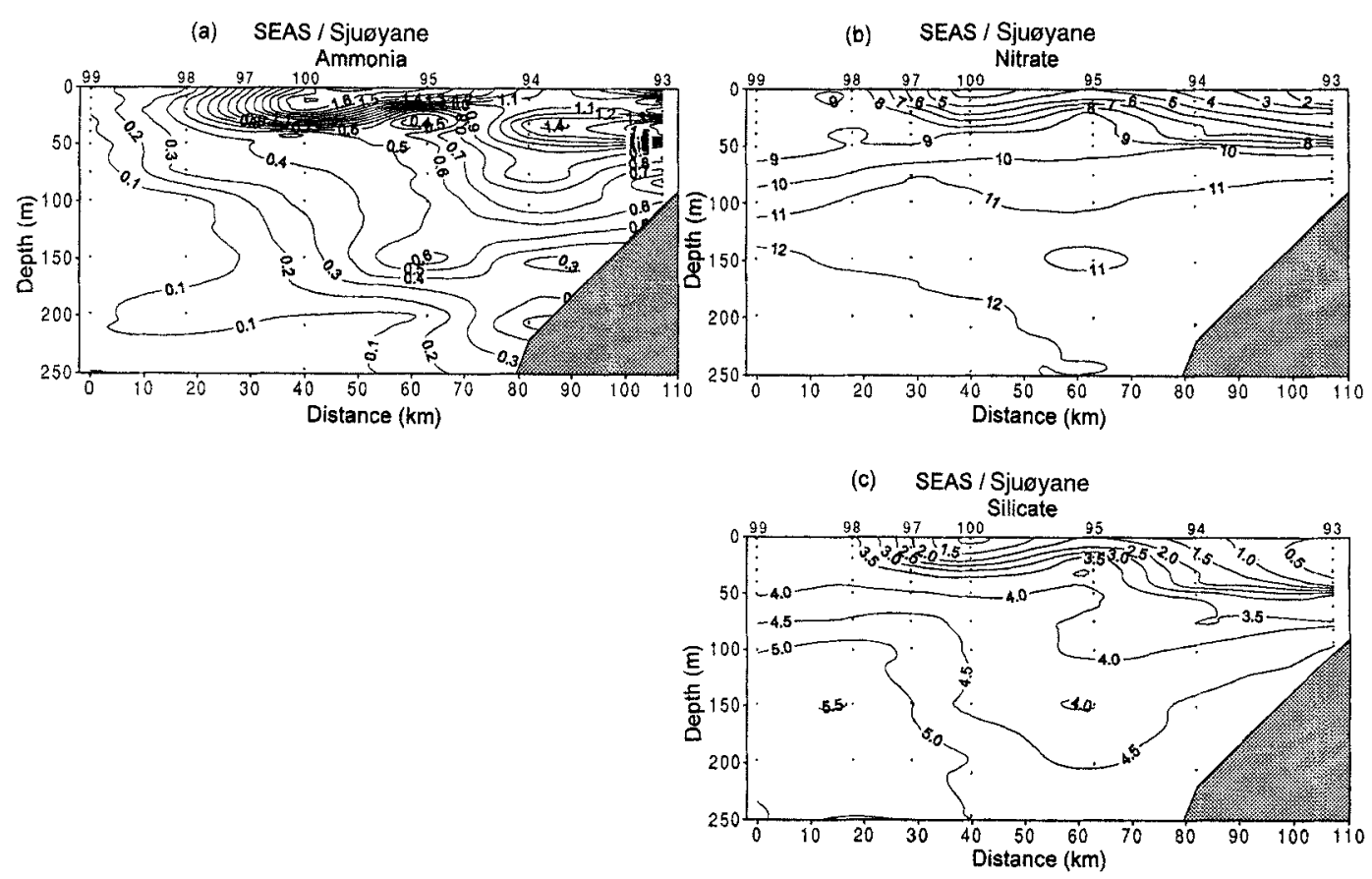

Fig. 7. Vertical distribution of: (a) ammonia $(\mu \mathrm{M})$; (b) nitrate $(\mu \mathrm{M})$; and (c) silicate $(\mu \mathrm{M})$ along the Sjuøyane transect. 
seriata complex and Thalassiosira bioculata (Poulin 1990).

\section{North of Svalbard}

Transect IV: Sjuøyane ("Seven Islands") (Figs. $6,7)$

The area was occupied by cold Arctic Water ( $\mathrm{T}=-1.7$ to $3.0^{\circ} \mathrm{C}, \mathrm{S}=33.5$ to $34.8 \mathrm{psu}$ ) in the upper $80-100 \mathrm{~m}$. Underneath this layer, the warmer and more saline Atlantic Water ( $\mathrm{T}=3.0^{\circ} \mathrm{C}, \mathrm{S}>34.8 \mathrm{psu}$; Fig. 6) was present, with typical nutrient values $\left(\mathrm{NO}_{3}>11 \mu \mathrm{M}\right.$, $\mathrm{SiO}_{4}=4.5 \mu \mathrm{M}$; Fig. 7). This area was completely covered by ice (10/10) except at the Svalbard shelf station, although here cold water $\left(\mathrm{T}=-1.0^{\circ} \mathrm{C}\right)$ was observed at the surface. A surface layer of rather fresh water, possibly from ice melt, was found in the central area of the section.

Chlorophyll- $a$ values were low $\left(<1.0 \mu \mathrm{g} \mathrm{l^{-1 }}\right.$; Table 2), with a maximum of only $0.8 \mu \mathrm{g}^{-1}$ (station 94) at a depth of $30 \mathrm{~m}$ (Fig. 6). Extending from the shelf toward the middle of the section, nutrient consumption and depletion (especially for silicate; Fig. 7c) had occurred, but with no corresponding increase in phytoplankton abundance or biomass (mean biomass about $\left.6 \mu \mathrm{g} \mathrm{Cl}^{-1}\right)$. However, an increase in ammonium concentration from 0.2 to $1.6 \mu \mathrm{M}$, was observed at stations 98 and 100, respectively (Fig. 7a). A mixture of autotrophic and heterotrophic flagellates was found (Table 5), together with some ice algae species such as Navicula and Nitzschia.

\section{Transect V: north-eastern slope (not shown)}

Ice cover was $10 / 10$ and composed of heavy pack ice ( 2 to $3 \mathrm{~m}$ thick; Fig. 2). Arctic Water was present from the surface to $100 \mathrm{~m}$ depth. Nutrient concentrations in this layer were high $\left(\mathrm{SiO}_{4}=3-\right.$ $\left.5 \mu \mathrm{M}, \mathrm{NO}_{3}=8-10 \mu \mathrm{M}, \mathrm{PO}_{4}=0.5-0.6 \mu \mathrm{M}\right)$. Beneath the surface layer, Atlantic Water was recognized by its relatively high temperature $\left(\mathrm{T}>2.5^{\circ} \mathrm{C}\right)$ and waters at this depth were slightly under-saturated with oxygen.

Chlorophyll- $a$ and phytoplankton abundance were the lowest recorded during this SEAS cruise (Fig. 5); chlorophyll- $a$ values did not exceed $0.5 \mu \mathrm{g} \mathrm{I}^{-1}$, and phytoplankton biomass was about $2 \mu \mathrm{g} \mathrm{Cl}^{-1}$. Small flagellates (including Phaeocystis), naked dinoflagellates (Gymnodinium spp.), Cryptophyceans and some diatoms (Chaetoceros socialis and Fragilariopsis cylindrus) were pres- ent. Ice algae, such as Melosira arctica and Nitzschia frigida, were found in long chains from the undersides of ice floes and in some net samples.

\section{Transect VI: Kvitøya (not shown)}

The transect crossed a small trough and was completely ice-covered (Fig. 2). Cold Arctic Water occupied the upper $75 \mathrm{~m}\left(\mathrm{~T}<-1.0^{\circ} \mathrm{C}\right)$. At the eastern side of the trough, chlorophyll levels were surprisingly high (station 119; Table 4), in comparison to the more northern waters, with values reaching $4.4 \mu \mathrm{g} \mathrm{I}^{-1}$ at $80^{\circ} 44.8^{\prime} \mathrm{N}$. This bloom, more typical of the marginal ice zone, was dominated mainly by the diatom Chaetoceros socialis $\left(4 \times 10^{6}\right.$ cells $\left.1^{-1}\right)$ and by the prymnesiophycean Phaeocystis pouchetii $\left(10^{6}\right.$ cells $\left.\mathbf{l}^{-1}\right)$. Total biomass reached $121 \mathrm{~g} \mathrm{Cl}^{-1}$. At the same station a corresponding increase in silicate uptake at the surface was observed with concentrations of 0.4 to $0.8 \mu \mathrm{M}$ in the upper $10 \mathrm{~m}$, in contrast with 1.8 to $4.4 \mu \mathrm{M}$ at the neighbouring stations.

\section{Central Barents Sea, east of Svalbard}

Undertaken a month apart, two central Barents Sea transects, I and VII, crossed the Barents Sea Polar Front and the marginal ice edge. Transect VII extended farther north (Fig. 1).

Transect I: Barents Sea Polar Front (Figs. 8, 9) Ice cover ( 8 to 10/10; Fig. 2) and thickness $(140 \mathrm{~cm})$ decreased steeply towards the south (12/10 cover, thin ice): the marginal ice edge was located at about $77^{\circ} 27^{\prime} \mathrm{N}$. The Barents Sea Polar Front (BSPF), was evident in both the salinity and temperature profiles, although more clearly demonstrated in the latter. Water temperatures increased from below $-1.5^{\circ} \mathrm{C}$ to above $1.0^{\circ} \mathrm{C}$ (Fig. 8a) from north to south over a distance of about $40 \mathrm{~km}$ (at ca. $50 \mathrm{~m}$ depth). Stratification of the water column was dominated by salinity and increased towards the south (Fig. 8b). The 34.25 isohaline was found at depths of between 25 and $40 \mathrm{~m}$ for the whole transect, indicating the presence of meltwater at the surface. Towards the south, the high concentration of nutrients at the surface (upper $50 \mathrm{~m}$ ), especially nitrate and silicate, decreased to depleted levels (Fig. 9b, d).

Phytoplankton distribution and species composition varied. Chlorophyll- $a$ concentration $\left(>2.5 \mu \mathrm{g} \mathrm{l}^{-1}\right), \quad$ phytoplankton abundance 

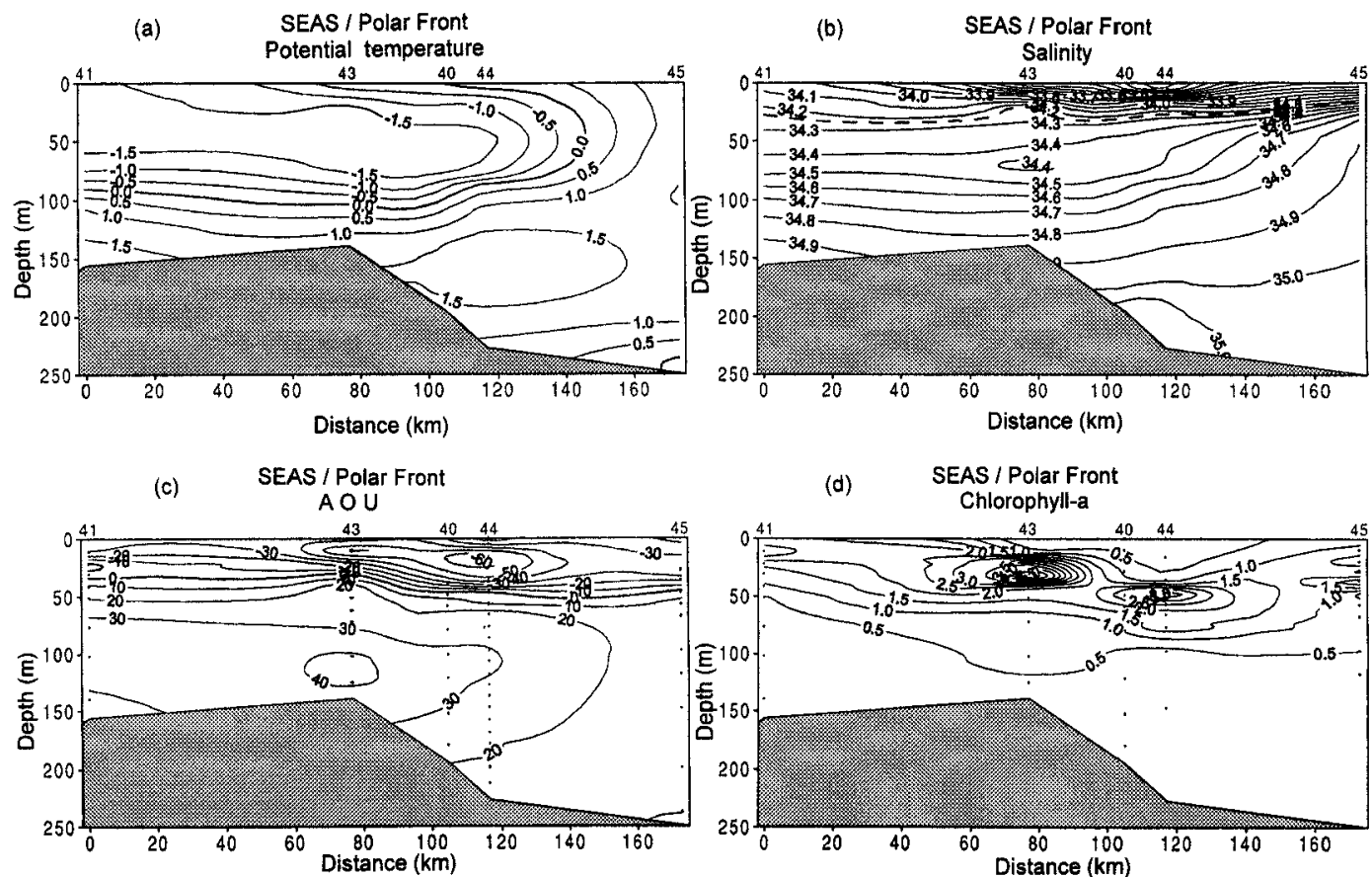

Fig. 8. Vertical distribution of: (a) potential temperature ( $\mathrm{C}$ ); (b) salinity (psu); (c) Apparent Oxygen Utilization (AOU) ( $\mu \mathrm{M}$ ); and (d) chlorophyll- $a\left(\mu \mathrm{g}^{-1}\right)$ along the Polar Front transect.
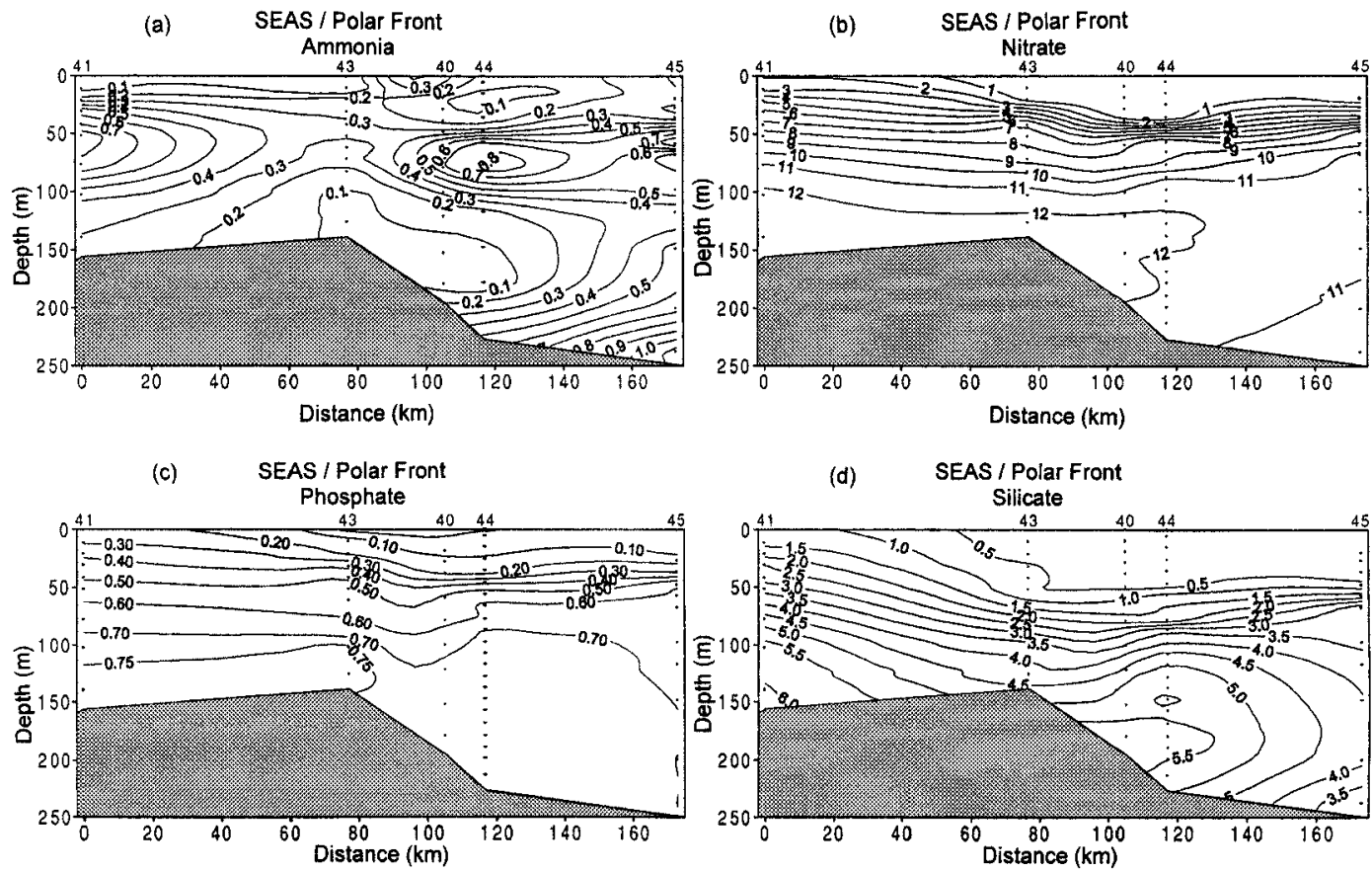

Fig. 9. Vertical distribution of: (a) ammonia $(\mu \mathrm{M})$; (b) nitrate $(\mu \mathrm{M})$; (c) phosphate; and (d) silicate ( $\mu \mathrm{M})$ along the Polar Front transect. 


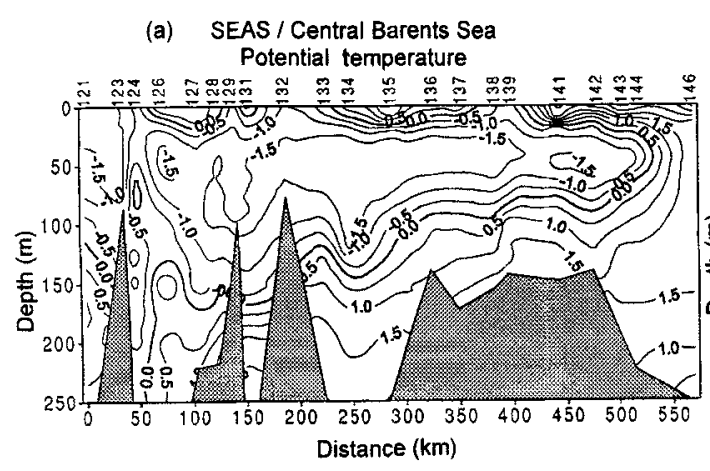

(c) SEAS / Central Barents Sea

AOU

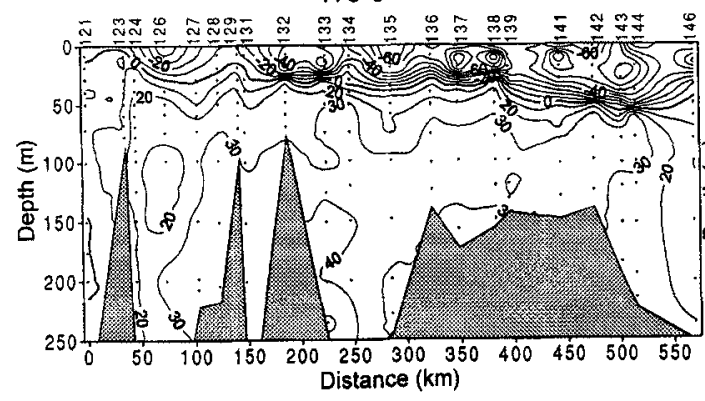

(b) SEAS / Central Barents Sea

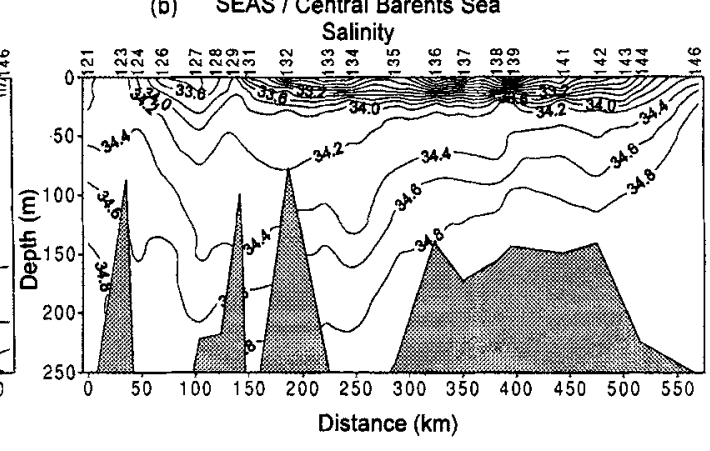

(d) SEAS / Central Barents Sea Chlorophyll-a

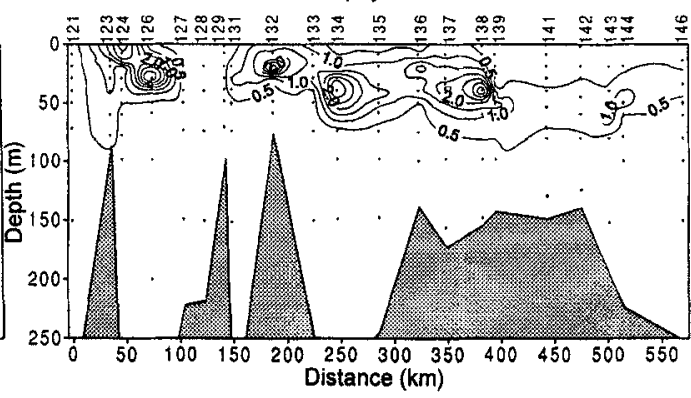

Fig. 10. Vertical distribution of: (a) potential temperature $\left({ }^{\circ} \mathrm{C}\right)$; (b) salinity (psu); (c) Apparent Oxygen Utilization (AOU) ( $\left.\mu \mathrm{M}\right)$; and (d) chlorophyll- $a\left(\mu \mathrm{g} \mathrm{l}^{-1}\right)$ along the central Barents Sea transect.

$\left(2.7 \times 10^{6}\right.$ cells $\left.\mathrm{l}^{-1}\right)$ and biomass $\left(78 \mu \mathrm{g} \mathrm{C}{ }^{-1}\right)$ were relatively high. The phytoplankton community was dominated by the prymnesiophycean Phaeocystis pouchetii (Table 5) and by the diatoms Nitzschia grunowii, Thalassiosira antarctica and Chaetoceros socialis, typical for a marginal ice "spring" bloom community.

The chlorophyll maxima increased in depth towards the south, reaching $6.8 \mu \mathrm{g} \mathrm{l}^{-1}$ in the central part of the section (at a depth of 30 $50 \mathrm{~m}$; Fig. $8 \mathrm{~d}$ ); a corresponding decrease in AOU levels (Fig. 8c) was also noticed. Maximum phytoplankton abundance occurred at $50 \mathrm{~m}$ depth, which was slightly deeper than that of the chlorophyll-a. Phaeocystis pouchetii represented more than $70 \%$ of this "Atlantic side" community. Dynobrion balticum, a characteristic species for frontal zones, and Lauderia borealis were well represented.

High concentration of ammonia $(0.8 \mu \mathrm{M})$ in the northernmost and central area of the transect occurred at 50 and $70 \mathrm{~m}$ depths, respectively (Fig. 9), together with an increase of phaeopigments - indicative of grazing.
Transect VII: central and northern Barents Sea (Figs. 10, 11, 12)

This north-south transect ran from the northern Barents Sea, south of Kvitøya $\left(80^{\circ} 41.9^{\prime} \mathrm{N}\right)$, across the BSPF into the southern Barents Sea (Fig. 1, Table 1), the latter part (from station 138) retracing transect sampled a month earlier. The marginal ice edge had receded by about $400 \mathrm{~km}$ and was now located at $80^{\circ} 20^{\prime} \mathrm{N}$, with heavy pack ice tongues $(8 / 10)$ reaching up to $81^{\circ} 41.9^{\prime} \mathrm{N}$.

Surface salinity (Fig. 10b) was much lower than a month earlier along the whole transect, with the exception of the northernmost end of the transect. Beneath the low salinity surface water, cold ( $\mathrm{T}\rangle$ $\left.-1.0^{\circ} \mathrm{C}\right)$ and more saline $(34.0<\mathrm{S}<34.5 \mathrm{psu})$ water was found at depths from 50 to $150 \mathrm{~m}$ to the north of the Polar Front (Fig. 10b).

The BSPF was again evident in the temperature profiles; maximum gradients occurred between stations 143 and 146 at $50 \mathrm{~m}$ depth. Underneath this layer, a warmer, more saline and higher in nutrient water mass was present (Fig. 11). These waters had low oxygen concentrations, indicative of waters with Atlantic origin, as Polar Front 
(a) SEAS / Central Barents Sea Ammonia

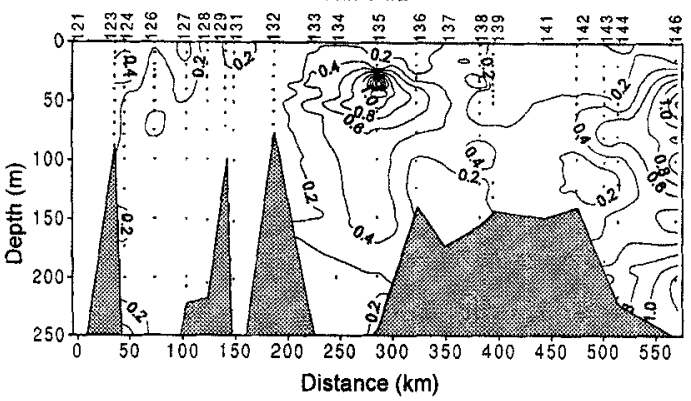

(c) SEAS / Central Barents Sea Phosphate

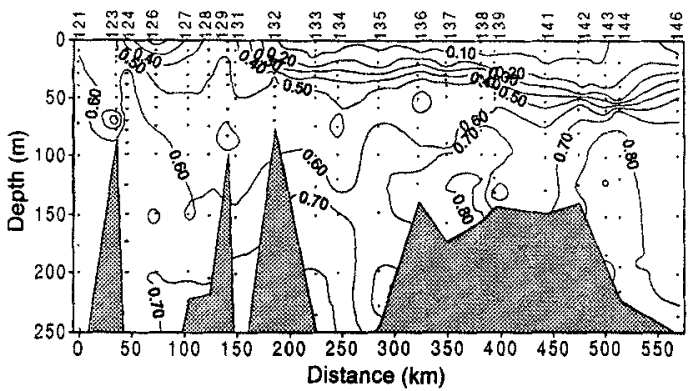

(b) SEAS / Central Barents Sea Nitrate

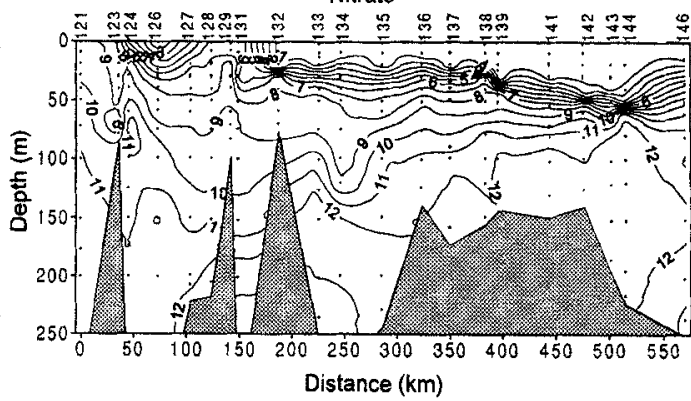

(d) SEAS / Central Barents Sea Silicate

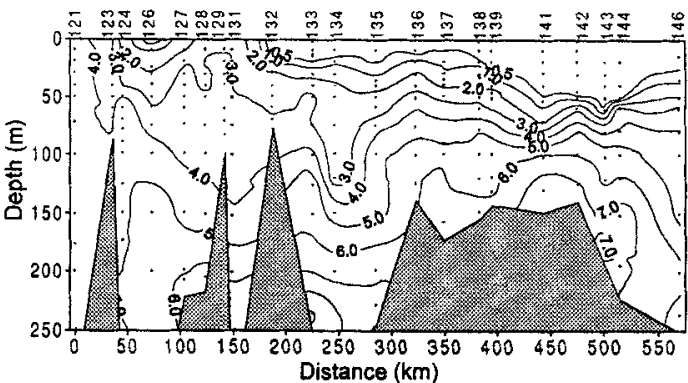

Fig. 11. Vertical distribution of: (a) ammonia $(\mu \mathrm{M})$; (b) nitrate $(\mu \mathrm{M})$; (c) phosphate; and (d) silicate $(\mu \mathrm{M})$ along the central Barents Sea transect.

Water (Loeng 1991). Nitrate, silicate and phosphate were depleted at the surface at station 132; the thickness of this inorganic nutrient-exhausted layer increased to more than $50 \mathrm{~m}$ at the southernmost stations (Fig. 11b, c, d). The surface peak of chlorophyll-a (3.4 $\mu \mathrm{g}^{-1}$, Fig. 10d) was found in the marginal ice edge zone. Several Deep Chlorophyll Maxima (DCM) were observed along the transect with chlorophyll- $a$ values of $>3 \mu \mathrm{g} \mathrm{l}^{-1}$ between 20 and $40 \mathrm{~m}$ depth. The depth of the DCM increased from the ice edge towards the south, forming a characteristic picture for marginal ice edge bloom development at the receding ice edge (Rey \& Loeng 1985; Skjoldal et al. 1987).

In the surface layer, phytoplankton blooms were dominated by Phaeocystis pouchetii and Chaetoceros socialis (Table 5). Phytoplankton abundance and biomass reached values of up to $5 \times 10^{6}$ cells $1^{-1}$ and $63 \mu \mathrm{g} \mathrm{Cl}^{-1}$ at the marginal ice edge. A notable decrease in abundance of Chaetoceros socialis was observed to the south of the Kvitøya transect where the species was represented mainly by resting spores.
Proceeding to the south, the phytoplankton peak abundance descended to depths of between 20 and $40 \mathrm{~m}$ with maxima $>10^{7}$ Phaeocystis cells ${ }^{-1}$ (Fig. 12). In this region, the vertical profile of cell abundance was heterogeneous due to the patchy distribution of Phaeocystis pouchetii. Diatom abundance steeply decreased towards the south, disappearing from the surface in the southernmost region (Fig. 12). Auto- and heterotrophic dinoflagellates, crysophytes (i.e. Dinobryon balticum) and nanoflagellates were present at these stations and were representatives of an "Atlantic community" in a post-bloom state.

\section{Net and new production estimates in the central Barents Sea}

Net community primary production occurred throughout the central Barents Sea section, except at the two southernmost stations (stations 144, 146), with rates being higher proceeding to the north (Table 3). In the northern Barents Sea (east of Svalbard) production estimates for both net and new production were similar and rates ranged from 

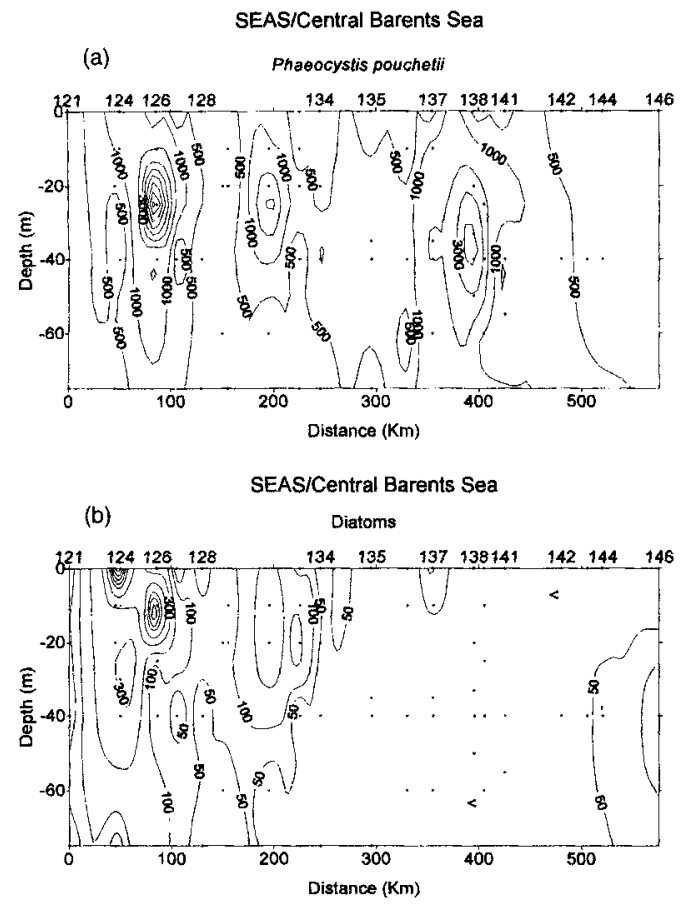

Fig. 12. Vertical distribution of: (a) Phaeorystis pouchetii; and (b) total diatom abundance $\left(10^{3}\right.$ cells $1^{-1}$ ), along the central Barents Sea transect.

0.58 to $1.44 \mathrm{~g} \mathrm{C} \mathrm{m}^{-2} \mathrm{day}^{-1}$ (for stations 132-137). This suggests that new production was the dominant fraction of the high net community production. In contrast, for the southern part of the section (repeated stations), net community and new production estimates were not in agreement, suggesting that both new and regenerated forms of production were active. In particular, regenerated production was the only form found at the southernmost stations (143, 144 and 146), whereas new production was found to occur at appreciable rates to the north of the BSPF (stations 138 and 142), where both forms of production were active, with maxima of $0.36 \mathrm{~g} \mathrm{C} \mathrm{m}^{-2}$ day $^{-1}$ (new production) and $0.62 \mathrm{~g} \mathrm{C} \mathrm{m}^{-2}$ day $^{-1}$ (net production) in the upper mixed layer (station 43/142).

\section{Discussion}

In the warm and ice-free waters to the west of Svalbard, a post-bloom situation was observed in early July. Phytoplankton biomass was low and species composition was dominated by flagellates and representative of a summer Atlantic community (see Weslawski et al. 1993). Nutrients were generally not depleted, whilst some ammonia peaks were found to correspond to an abundant zooplankton standing stock (Fransz et al. 1992). Andreassen et al. (1996) observed that there was a low vertical flux of organic matter (POC 25$30 \mathrm{mg} \mathrm{C} \mathrm{m}^{-2}$ day $^{-1}$ ) with respect to particulate phytoplankton carbon, and a predominance of faecal pellets and detritus in the sedimented material. These observations corroborated our data and indicated that to the west of Svalbard phytoplankton biomass was effectively grazed and, thus, controlled by the zooplankton community.

To the north of Svalbard, the waters were covered with thick ice and Cold Arctic Water overlay the deep $(>100 \mathrm{~m})$ warmer Atlantic Water. In this region, chlorophyll- $a$ and phytoplankton biomass values were very low. Phytoplankton was composed of a mixture of autotrophic and heterotrophic flagellates. Despite high nutrient concentrations, the low light levels under the ice and unstratified (well-mixed) waters (with little evidence of meltwater) did not enhance significant phytoplankton growth. In fact, new production levels were low, around of $0.1 \mathrm{~g} \mathrm{C} \mathrm{m}^{-2}$ day $^{-1}$ for $100 \mathrm{~m}$ integrated depth ( $\mathrm{F}$. Sorensson pers. comm.), which confirms previous production estimates for this region (see Strömberg 1989). However, several colonies of Melosira arctica were found at the northern stations, and also collected in the sedimented material. These species are representative of a sub-ice summer community (Syvertsen 1991). It has been suggested that the major input of organic carbon in this ice-covered region is produced by under-ice flora. However, some carbon production can be attributed to algal growth as indicated by silica consumption (synonymous with diatom growth) which may maintain a high zooplankton biomass (copepods, mainly Calanus finmarchicus, Calanus glacialis and Calanus hyperboreus; Fransz et al. 1992). Because the sedimentation rate was low (17 to $26 \mathrm{mg} \mathrm{C} \mathrm{m}^{-2}$ day $^{-1}$ ) and sinking material was represented mainly by faecal pellets (Andreassen et al. 1996), it is probable that at some time prior to sampling, phytoplankton growth had occurred and been instantly consumed by copepods. This pulse of carbon was not reflected in the short-term sediment trap data.

In the Barents Sea, a typical situation of enhanced phytoplankton development at the 
receding ice edge (Rey \& Loeng 1985; Sakshaug 1989) was observed. The ice edge receded from south to north leaving nutrient-impoverished water behind. The ice edge bloom was observed at $77^{\circ} 27^{\prime}$ in late June and at $80^{\circ} 41^{\prime}$ and $80^{\circ} 20^{\prime} \mathrm{N}$, a month later. Water column stability, induced by meltwater, favoured the growth of phytoplankton (see Strass \& Nöthig 1996). High chlorophyll values were found at the bloom sites and phytoplankton communities were dominated by diatoms and the prymnesiophycean, Phaeocystis pouchetii.

The decrease in abundance of Chaetoceros socialis in the water column from $80^{\circ} 41^{\prime}$ to $80^{\circ} 20^{\prime} \mathrm{N}$ and the appearance of resting spores of the same species, found deeper in the water column, were corroborated by results from the sediment traps (Andreassen et al. 1996). The highest sedimentation rate of chlorophyll- $a$ was found at $80^{\circ} 20^{\prime} \mathrm{N}$, where the resting spores of $C$. socialis, with high silica content, represented the major component of the sedimented material. As Bienfang (1981) demonstrated, the heavily silicified resting spores of $C$. socialis sink five times faster than vegetative cells. It is proposed that $C$. socialis is the main species responsible for the depletion of silica in the northern Barents Sea, as also reported for the central Barents Sea by Rey \& Skjoldal (1987).

The new production estimates, obtained by nutrient uptake, confirm that the marginal ice zone is a site of high phytoplankton activity. These estimates (up to $1.44 \mathrm{~g} \mathrm{C} \mathrm{m}^{-2}$ day $^{-1}$ ) compare favourably with the values obtained using the ${ }^{14} \mathrm{C}$ method for estimation during the growth season in the Barents Sea (Savinov 1992), in the Fram Strait (Codispoti et al. 1991) and the Northwestern Polynya, Canadian Arctic (Pesant et al, 1996).

To the south of the ice edge, where several Deep Chlorophyll Maxima (DCM) occurred, Phaeocystis dominated the phytoplankton communities. In contrast, phytoplankton sedimentation appeared to be low, and the settled organic matter was composed of mainly faecal material and carbon of unknown origin (Gonzalez et al. 1998). Nutrient depletion at the surface was very pronounced and phytoplankton biomass was low and concentrated at the DCM. Species composition was typical of a post-bloom state, mainly represented by auto- and heterotrophic flagellates, large heterotrophic dinoflagellates and several ciliates. The specific phytoplankton composition was probably due to the low light conditions at the depth of the pycnocline.

A slight increase in nutrients was observed at the southernmost stations, which suggested some loss of carbon. However, estimates based on oxygen production still indicated that primary production was occurring. In this region, the rates of primary production were much lower than those at the ice edge. but this rate was still detectable and within the range of values reported in the literature for blooms in the late phase in polar areas (Jennings 1984; Sambrotto et al. 1986; Goeyens et al. 1991; Savinov 1992). These apparently inconsistent results (loss of carbon on one hand, some production on the other) can be explained by the fast removal of carbon due to regeneration processes within the euphotic layer. In this region, the contribution of regenerated production consistently supported the net community production and even dominated at the southernmost stations. Peaks in ammonia concentration corresponded to an increase in mesozooplankton biomass and, therefore, grazing was considered to have reduced the phytoplankton biomass in this region. However, the presence of several protozoans in the south-east stations indicated that grazing by microzooplankton could be more important than grazing by mesozooplankton, as demonstrated by Hansen et al. (1996) for the same area. Furthermore, the presence of microzooplankton would be important for the retention of suspended matter in the upper water column (I. Andreassen pers. comm.).

In conclusion, phytoplankton biomass and composition in the waters around Svalbard vary considerably and are shown to be dependent upon hydrological, hydrochemical and biological factors. as well as the cover and thickness of sea ice. Phytoplankton biomass is generally low and grazing by micro- and mesozooplankton exerts a major control. The copepods and protozoans appear to be able to respond immediately to any increase in phytoplankton biomass and, hence, grazing reduces the standing stock. Similarly, zooplankton grazing control has been observed in under-ice communities (Syvertsen 1991). Sedimentation rates of living cells from the euphotic zone were low and the sinking material consisted mainly of faecal pellets (Andreassen et al. 1996), further illustrating the importance of zooplankton grazing. In fact, sedimentation rates in the benthic layer were low throughout the study area (Hulth et al. 1996). 
It is only at the ice edge that the zooplankton community seems unable to control the spring phytoplankton bloom and that the sedimentation of living phytoplankton seems to be the dominant factor. Here, the increase in stratification of the waters and the availability of nutrients, coupled with an increase in insolation, result in the development of spring phytoplankton blooms and a pulse of carbon to the benthos.

Production estimates have revealed, for the first time, that both new and regenerative production occur to the north of the Barents Sea Polar Front in summer. Maximum production occurred at the receding ice edge and new production prevailed in the northern part of the section, decreasing towards the BSPF. South of the BSPF, the contribution of regenerated production consistently supported or even dominated the net community production.

Acknowledgements. - The Study of the European Arctic Shelf (SEAS) was undertaken as part of the European "Polarstern" Study (EPOSII), sponsored by the European Science Foundation. We would like to thank G. Hempel and E. Rachor, as chief scientists during the EPOS cruise. Thanks are also due to the captain of the RV "Polarstern" and the crew. We also are grateful to F. Sorensson, G. Fransz, H. Gonzalez, M. Inall and P. Parker for information that was useful in the preparation of the manuscript, and to F. Bianchi and S. Tortato for the help with the drawings. We are indebted to the European Science Foundation (ESF) and to Italy"s Progetto Nazionale Ricerche in Antartide.

\section{References}

Andreassen, I., Nöthig, E. M. \& Wassmann, P. 1996: Vertical particle flux on the shelf off northern Spitsbergen. Mar. Ecol. Prog. Ser. 137, 215-218.

Båmstedt, U., Eilertsen, H. C., Tande. K. S., Slagstad. D. \& Skjoldal, H. R. 1991: Copepod grazing and its potential impact on phytoplankton development in the Barents Sea. In E. Sakshaug et al. (eds): Proceeding of the Pro Mare Symposium on Polar Marine Ecology, Trondheim. 12-16 May 1990. Polar Res. 10, 339-353.

Bianchi, F., Boldrin, A., Cioce, F., Diekmann, G., Kuosa, H., Larsson. A. M., Nöthig, E. M.. Sehlstedt, P.I., Socal, G. \& Syvertsen, E. E. 1992: Phytoplankton distribution in relation to sea ice, hydrography and nutrients in the northwestern Weddell Sea in early spring. Polar Biol. 12, 225-235.

Bienfang, P. K. 1981: Sinking-rate of heterogeneous temperate phytoplankton populations. J. Plankton Res. 3. 235-253.

Catalano, G. 1987: An improved method for the determination of ammonia in seawater. Mar. Chem. 20, 289-295.

Codispoti. L. A., Friederich, G. E., Sakamoto, C. M. \& Gordon, L. 1. 1991: Nutrient cycling and primary production in the marine systems of the Arctic and Antarctic. J. Mar. Syst. 359384

Edler, L. 1979: Recommendations on methods for marine biological studies in the Baltic Sea. Phytoplankton and chlorophyll. BMB (Baltic Marine Biologists) Publ. 5.

Eilertsen, H. C., Taasen, J. P. \& Weslawski, J. M. 1989: Phytoplankton studies in the fjords of west Spitsbergen physical environment and production in spring and summer. J. Plankton Res. 11, 1245-1260.

Evans, C. A., O'Reilly, J. E. \& Thomas, J. P. 1987: A handbook for the measurement chlorophyll $a$ and primary production. BIOMASS Sci. Ser. 8.

Fransz. H. G., Gonzalez, H. E., Greave, M., Mathieu, T., Meyer, U., Passelaige, F. \& Timofeev, S. F. 1992: Zooplankton. In E. Rachor (ed): Scientific Cruise Report of the 1991 Arctic Expedition ARK VIII/2 of RV POLARSTERN (EPOS II: Study of the European Arctic Shelf, "SEAS", of the European Science Foundation). Ber. Polarforsch. 115, 63-80.

Goeyens, L.. Sörensson, F., Trèguer, P., Morvan, J., Panouse, M. \& Dehairs, F. 1991: Spatiotemporal variability of inorganic nitrogen stocks and uptake fluxes in the Scotia-Weddell confluence area during November and December 1988. Mar. Ecol. Prog. Ser. 77, 7-19.

Gonzalez, H. E., Nöthig. E.-M., Duman, M. \& Schauer, U. 1998 (unpubl. ms.): Sedimentation of biogenic and lithogenic particles in the central Barents Sea (Arctic) over a one year period.

Grasshoff, K., Ehrardt, M. \& Kremling, K. 1983: Methods of seawater analysis. Weinheim: Verlag Chemie.

Hansen, B., Christiansen, S. \& Pedersen, G. 1996: Plankton dynamics in the marginal ice zone of the central Barents Sea during spring: carbon flow and structure of the grazer food chain. Polar Biol. 16, 115-128.

Hulth, S., Hall, P. O. J., Blackburn, T. H. \& Landen, A. 1996: Arctic sediments (Svalbard): pore water and solid phase distribution of C, N, P and Si. Polar Biol. 16, 447-462.

Inall, M. \& Parker, P. 1992: Sea ice. In E. Rachor (ed): Scientific Cruise Report of the 1991 Arctic Expedition ARK VIII/2 of RV POLARSTERN (EPOS II: Study of the European Arctic Shelf, "SEAS", of the European Science Foundation). Ber. Polarforsch. $115,43-51$.

Jenkins, W. J. \& Wallace, D. W. R. 1992: Tracer based inferences of new primary production in the sea. In P. G. Falkowski \& A. D. Woodhead (eds): Primary productivity and biogeochemical cycles in the sea. Pp. 299-316. New York: Environmental Science Research/Plenum Press.

Jennings, J. C., Gordon, L. I. \& Nelson, D. M. 1984: Nutrient depletion indicates high primary productivity in the Weddell Sea. Nature 309, 51-54.

Kendall, M. A. 1996: Are Arctic soft-sediment macrobenthic communities impoverished? Polar Biol. 16, 393-399.

Liddicoat, M. I., Tibbits, S. \& Buttler, E. I. 1975: The determination of ammonia in seawater. Limnol. Oceanogr. 20, 131-132.

Loeng, H. 1989: Ecological features of the Barents Sea. Northern Svalbard waters. In L. Rey \& V. Alexander (eds.): Proceedings of the 6th Conference of the Comite Arctique International. Pp. 327-365. Leiden: E. J. Brill.

Loeng, H. 1991: Features of the physical oceanographic conditions of the Barents Sea. In E. Sakshaug et al. (eds.): Proceedings of the Pro Mare Symposium on Polar Marine Ecology, Trondheim, 12-16 May 1990. Polar Res. 10, 5-18.

Luchetta. A., Lipizer, M. \& Socal. G. in press: Temporal evolution of primary production in the central Barents Sea.J. Mar: Syst.

Meh1, S. 1991: The northeast Arctic cod stock's place in the Barents Sea ecosystem in the 1980s: an overview. In E. 
Sakshaug et al. (eds): Proceeding of the Pro Mare Symposium on Polar Marine Ecology. Trondheim, 12-16 May 1990. Polar Res. 10, 525-534.

Minas. H. J. Minas, M. \& Packard, T. T. 1986. Productivity in upwelling areas deduced from hydrographic and chemical fields. Limnol. Oceanogr. 31(6), 1182-1206.

Mitchell, B. G. \& Holm-Hansen, O. 1991: Observation and modeling of the Antarctic phytoplankton crop in relation to mixing depth. Deep-Sea Res. 38, 981-1007.

Nesvetova, G. I. \& Rhyzhov, V. M. 1987: Long-term variations of the biogenous elements content and primary production in the Barents Sea waters. In H. Loeng (ed.): The effects of oceanographic conditions on distribution and population dynamics of commercial fish stocks in the Barents sea. Proceedings of the third Soviet-Norwegian Symposium, Murmansk, 26-28 May 1986. Pp. 47-57. Bergen: Institute of Marine Research.

Pesant, S., Legendre, L., Grosselin, M., Smith, R. E. H., Kittner, G. \& Ramseier, R. O. 1996: Size-differential regimes of phytoplankton production in the Northeast Water Polynya $\left(77^{\circ}-81^{\circ}\right.$ N). Mar. Ecol. Prog. Ser. 142, 75-86.

Piepenburg. D., Chernova, N. V., von Dorrien, C. F., Gutt, J., Neyelov, A. V.. Rachor, E.. Saldanha, L. \& Schmid, M. K. 1996: Megabenthic communities in the waters around Svalbard. Polar Biol. 16, 431-446.

Poulin, M. 1990: Ice diatoms: the arctic. In L. Medlin \& J. Priddle (eds): Polar marine diatoms. Pp. 15-18. Cambridge: British Antarctic Survey.

Rachor, E. 1992: Summary and itinerary. In E. Rachor (ed.): Scientific Cruise Report of the 1991 Arctic Expedition ARK VIII/2 of RV POLARSTERN (EPOS II. Study of the European Arctic Shelf, "SEAS", of the European Science Foundation). Ber. Polarforsch. 115, 3-19.

Redfield, A. C., Ketchum. B. H. \& Richards, F. A. 1963: Influence of organisms on the composition of sea water. In $\mathrm{M}$. N. Hill (ed.): The sea. Vol. 2. Pp 26-77. New York: John Wiley.

Rey. F. \& Loeng, H. 1985: The influence of ice and hydrography conditions on the development of phytoplankton in the Barents Sea. In J. S. Gray \& M. E. Christiansen (eds.): Marine biology of polar regions and effects of stress on marine organisms. Pp. 49-63. London: John Wiley \& Sons.

Rey, F. \& Skjoldal, H. R. 1987: Consumption of silicic acid below the euphotic zone by sedimenting blooms in the Barents Sea. Mar. Ecol. Prog. Ser. 36, 307-312.

RAS (Russian Academy of Sciences) 1992: Phytoplankton in the Barents Sea. Apatity: Murmansk Marine Biological Institute.

Sakshaug, E. 1989: The physiological ecology of polar phytoplankton. In L. Rey \& V. Alexander (eds.): Proceedings 6th Conference of the Comite Arctic International. Pp. 61--89. Leiden: E. J. Brill.

Sakshaug, E., Hopkins, C. C. E. \& Øristland. N. A. (eds.) 1991: Proceedings of the Pro Mare Symposium on Polar Marine Ecology. Trondheim. 12-16 May 1990. Polar Res. 10.

Sambrotto, R. M., Niebauer, H. J., Goering, J. J. \& Iverson, R. L. 1986: Relationship among vertical mixing, nitrate uptake and phytoplankton growth during the spring bloom in the southeast Bering Sea middle shelf. Cont. Shelf Res. 5. 161 198.

Savinov, V. M. 1992: Spatial distribution of chlorophyll and primary production. In: Phytoplankton in the Barents Sea. Pp. 52-53. Apatity: Murmansk Marine Biological Institute, Russian Academy of Science.
Schauer, U. 1995: The release of brine-enriched shelf water from Storfjord into the Norwegian Sea. J. Geophys. Res. $100(C 8), 16015-16028$.

Skjoldal, H. R., Hassel, A., Rey, F. \& Loeng, H. 1987: Spring phytoplankton development and zooplankton reproduction in the central Barents Sea in the period 1979-1984. In H. Loeng (ed.): The effects of oceanographic conditions on distribution and population dynamics of commercial fish stocks in the Barents sea. Proceedings of the third Soviet-Norwegian Symposium, Mumansk, 26-28 Moy 1986. Pp. 59-89. Bergen: Institute of Marine Research.

Smetacek, V. 1975: Die Sukzession des Phytoplanktons der westlicher Kieler Butch. (The succession of phytoplankton in the western Bay of Kiel.) Ph.D. thesis, University of Kiel.

Smith, W. O., Jr. 1987: Phytoplankton dynamics in the marginal ice zones. Oceanogr. Mar. Biol. Annu. Rev. 25, 11-38.

Strass, V. \& Nöthig, E. M. 1996: Seasonal shifts in ice edge phytoplankton blooms in the Barents Sea related to the water column stability. Polar Biol. 16, 409-422.

Strathmann, R. R. 1967: Estimating the organic carbon content of phytoplankton from cell volume or plasma volume. Limnol. Oceanogr. 12, 411-418.

Strickland. J. D. \& Parsons. T. T. 1972: A practical handbook of seawater analysis. Bull. Fish. Res. Board Can. 167. Ottawa.

Strömberg, J. O. 1989: Northern Svalbard waters. In L. Rey \& V. Alexander (eds.): Proceedings of the 6th Conference of the Comité Arctique International. Pp. 402-426. Leiden: E. J. Brill.

Syvertsen, E. E. 1991: Jce algae in the Barents Sea: types of assemblages, origin and role in the ice edge phytoplankton bloom. In E. Sakshaug, E. et al. (eds): Proceeding of the Pro Mare Symposium on Polar Marine Ecology, Trondheim, 12 16 May 1990. Polar Res. 10, 277-287.

Utermöhl, E. 1958: Zur Vervolkommnung der quantitativen Phytoplankton-Methodik. (On improving the quantitative method for phytoplankton counts.) Mitteilungen der internationalen Vereinigung fur theoretische und Angewandte Limnologie 9, 1-38.

Venrick, E. 1988: The vertical distribution of chlorophyll and phytoplankton in the North Pacific central environment. $J$. Plankton Res. 10, 987-998.

Venrick, E. 1990: Phytoplankton in an oligotrophic ocean: species structure and interannual variability. Ecology 71 $1547-1563$.

Villafañe, V., Helbling, E. W. \& Holm-Hansen, O. 1993: Phytoplankton around Elephant Island, Antarctica. Distribution, biomass and composition. Polar Biot. 13, 183-191.

Vinje, T. \& Kvambekk. Å. S. 1991: Barents Sea drift ice characteristics. In E. Sakshaug et al. (eds.): Proceeding of the Pro Mare Symposium on Polar Marine Ecology, Trondheim, 12-16 May 1990. Polar Res. 10, 59-68.

Weeks, A. R., Fasham, M. J. R., Aiken. J.. Harbour., D. S., Read, J. F. \& Bellani, I. 1995: The spatial and temporal development of the Atlantic spring bloom during the JGOFS North Atlantic bloom experiment, 1989. J. Mar. Biol. Assoc. UK 73, 253-282.

Weslawski, J. M., Kwasniewski, S. \& Wiktor, J. 1993: Species communities and concentration of plankton. In K. Korzeniewski (ed.): Polar marine research (2). The results of Polish oceanographic investigations on interannual variability of the Greenland Sea energoactive zones. Pp 181-196. Sopot, Poland: Institute of Oceanology, Polish Academy of Science. 